\title{
WORKING
}

\section{Competition for Global Value Added: Export and Domestic Market Shares}

\author{
Rafael Cezar' ${ }^{1}$, Adrien Duguet, \\ Guillaume Gaulier $^{2}$ \& Vincent Vicard ${ }^{3}$
}

April 2017, WP \#628

\begin{abstract}
We propose a new "global" market share indicator that complements the traditional export market share analysis by accounting for the foreign value added embodied in the production process and for the performance of national firms on their domestic market. We also consider all the income from activities used in the production to address the manufacturing final demand, namely all activities within the manufacturing value chain. Our results show that the role of services is growing in global value chains. Interestingly, considering our global indicator makes the dynamics of market shares converge among large economies, which can be explained by a de-correlation between national and export performances. This de-correlation appears to reflect greater specialization within global manufacturing value chains.
\end{abstract}

Keywords: International trade, Market share, Value added, Global value chains, Globalization, Manufacturing industry.

JEL classification: F10, F60, L60.

\footnotetext{
${ }^{1}$ Banque de France ; Rafael.CEZAR@banque-france.fr

${ }^{2}$ Banque de France; Guillaume.GAULIER@banque-france.fr

${ }^{3}$ Banque de France; Vincent.VICARD@cepii.fr
}

Working Papers reflect the opinions of the authors and do not necessarily express the views of the Banque de France. This document is available on publications.banque-france.fr/en 


\section{NON-TECHNICAL SUMMARY}

Export market shares indicators have become a yardstick for measuring competitiveness. Using gross trade flows does however not allow distinguishing whether exports contain substantial domestic value added or a large proportion of imported inputs. Also, they do not consider the performance of firms in their domestic market, facing import competition. The global market share indicator developed in this paper proposes an approach to overcome these two limitations. Furthermore, the paper focuses on countries' pattern within the manufacturing global value chains, and considers all the incomes from activities used in the production to address the manufacturing final demand, including services.

\section{Market shares in exports \& global market shares (1995-2011)} (consolidated annual growth rate in \%)

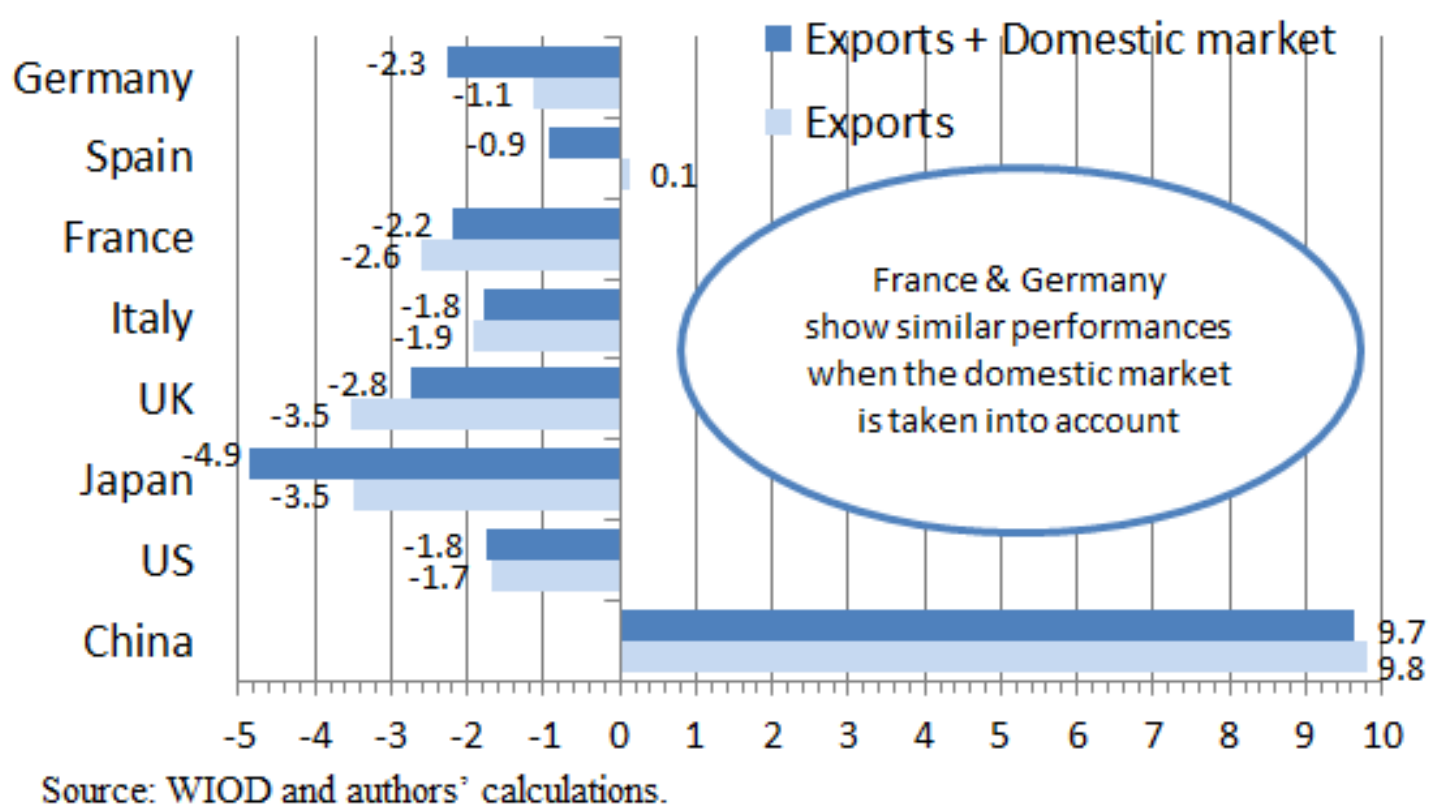

The import content of exports increased over the last two decades following the development of global value chains. The paper shows that despite this trend, export market shares computed from value added trade flows do not substantially affect the basic diagnosis based on gross trade flows. Interestingly, the analysis of all the tasks performed within the manufacturing global value chain gives a rather mixed diagnosis.

Taking into account all the contributions of services sectors to the manufacturing production reduces the international divergence in the dynamics of market shares indicators, notably between European countries. This is especially due to the increasing specialization of advanced economies in these service sectors. Our results highlight the importance of considering all activities within GVC to better assess the international performance of advanced economies. In particular, the French services industries increasingly contribute to the manufacturing value chain; whereas Germany stands at the opposite end of the spectrum as this deformation toward service tasks is less pronounced.

The convergence in the dynamics of market shares of most European countries is even stronger when we consider the performance of national firms in their own domestic market; i.e. using the global market share indicator. Thus, as the dispersion of global 
performances tightens, our results suggest that there is no polarization of the manufacturing production within the European Union.

To better understand these trends, we decompose our indicator into four main components: the countries' performance on exports and on their home markets; and the dynamics of foreign and domestic demands. The decomposition indicates a very low correlation between firms' external and domestic performances. Among the European countries in our sample; Spain and Germany, the two advanced economies that best maintain their export market shares between 1995 and 2011, do not reproduce this performance on their home markets. In contrast, for France and Italy, the loss of market shares is less pronounced in their home market than in foreign markets. This decorrelation between export and domestic performances seems to reflect greater specialization of domestic production within the manufacturing global value chain while final demand remains diversified.

We finally proceed to a second decomposition of market shares growth rates, which quantifies countries specific performances and captures the extent to which they reflect geographical or sectorial specializations, or other country specific determinants. The overall trend reported above is confirmed: countries' performances tend to converge if their domestic markets are taken into account along with export performances. For Germany and Japan, the geographical component indicates a good specialization. Nonetheless, taking into account the domestic market reverses the diagnosis, reducing their global performances. These results indicate a downward trend in their domestic demand or in their firms' domestic performance compared to the world average. The geographical specializations of the United Kingdom and Italy also indicate downward domestic markets. Conversely, French and Spanish domestic markets are relatively upward and improve their overall performance.

\section{Commerce global en valeur ajoutée : parts de marché nationales et à l'exportation}

\footnotetext{
RÉSUMÉ

Nous proposons un indicateur «global» de parts de marché qui complète les indicateurs traditionnels en tenant compte de la valeur ajoutée étrangère incorporée dans le processus de production et de la performance des entreprises nationales sur leur marché intérieur. Nous considérons aussi l'ensemble de revenus des activités utilisées dans la production pour répondre à la demande finale manufacturière, à savoir toutes les activités à l'intérieur de la chaîne de valeur manufacturière. Nos résultats indiquent un rôle croissant des services dans les chaînes de valeur mondiales. Fait intéressant, notre indicateur montre que la dynamique des parts de marché des grandes économies converge, ce qui s'explique par une décorrélation entre les performances sur les marchés nationaux et à l'exportation. Cette décorrélation semble refléter une plus grande spécialisation au sein des chaînes de valeur mondiales manufacturières.

Mots-clés: Commerce international, Parts de marché, Valeur ajoutée, Chaînes de valeur mondiales, Globalisation, Industrie manufacturière.

Les Documents de travail reflètent les idées personnelles de leurs auteurs et n'expriment pas nécessairement la position de la Banque de France. Ce document est disponible sur publications.banquefrance.fr
} 


\section{Introduction}

How an economy's competitiveness can be measured? This complex issue, which concerns the full and efficient use of domestic factors of production, is often reduced to the measurement of an economy's external competitiveness and/or the capacity of exporting firms to sell their products abroad. From this perspective, one of the most commonly used indicators is the trend in a country's share of world manufacturing goods exports. For example the growth in export market share over five years is one of the indicators taken into account in the European Commission's Macroeconomic Imbalances Procedure. The traditional diagnosis, based on this indicator, is that rich countries have been steadily losing market shares in favour of emerging countries, particularly China since 2001 (see Chart 1), with the exceptions of Spain, which has managed to maintain its market share, and Germany, whose loss has been limited, particularly in the first half of the 2000s. In Europe, the relative good performance of Germany is often highlighted whereas the one of Spain is less often noticed.

\section{Chart 1: Market shares in world gross exports of goods and services}

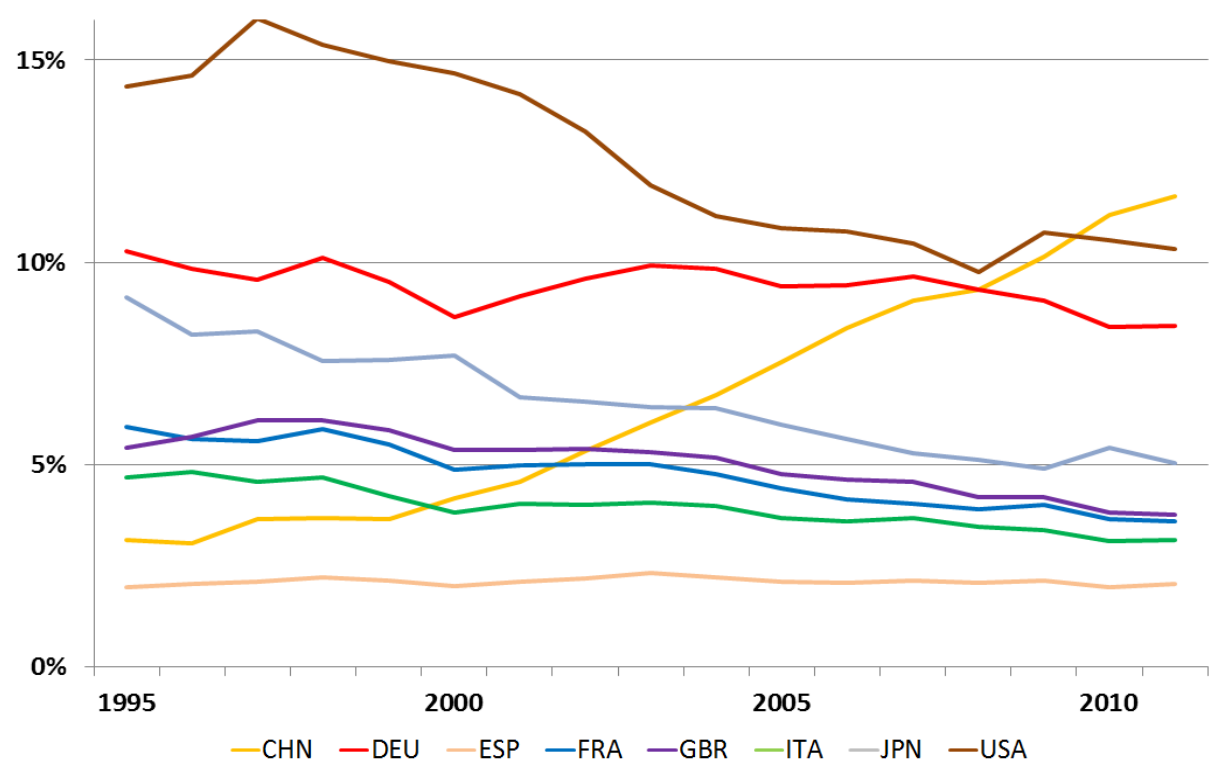

Source: WIOD and authors' calculations.

With the emergence of global value chains, exporting firms use an increasing share of imported inputs in their production process (Amador et al, 2015). Baldwin (2012) insists in the development of these chains and the increasing weight of intermediate input in world trade. Such process of international fragmentation of production might distort the diagnosis on competitiveness based on gross data (Bems et al, 2011). In a world with fragmented production chains, usual gross trade statistics indeed lead to a double count of trade flows of 
intermediate goods and services. These statistics consequently overestimate the domestic value added content in countries exports. Kraemer et al. (2011) illustrate the phenomenon through the iPhone production chain. Critical components (hard drive, processors...), which represent close to $50 \%$ of the factory price, are produced mainly in South Korea and the United States $^{1}$; whereas China only intervenes at the assembly stages that represent less than $12,5 \%$ of this price. However, the full product price is accounted in the Chinese exports. Consequently, traditional trade statistics count several times South-Korean and American inputs incorporated in several export flows, overestimating traditional trade flows and also the value added produced by each country within the global value chain (Benkovskis et al, 2015). Therefore it is important to use a renewed approach of trade statistics, measured in value added rather than in gross flows. The value added approach enables to take into account the domestic and import contents of exports and to assess the trend in value added produced domestically and exported (Daudin et al, 2006; Johnson et al, 2012).

In order to consider these new developments in the international organisation of production, our paper proposes a new measure of countries' performance within GVCs, the global market share, based on value added data. It takes into account the national value added used to address the world manufacturing final demand, whatever the origin of final demand (domestic or foreign). Hence, the indicator considers the performance of national firms ${ }^{2}$ in foreign markets but also in their domestic market. Considering the home market is important because it is often the main market for firms. Indeed, in an open economy, countries competitiveness is assessed by its capacity to serve international markets but also their home market coping with international competition. Therefore, the indicator we propose gets around two main issues of traditional market shares analysis: i/ it identifies the import content in output and takes into account the sole domestic value added in trade flows, and ii/ it considers the performance of domestic firms on their domestic market against imports.

Our paper focuses on countries pattern within the manufacturing global value chains - whose size is different from that of the manufacturing sector. Differently of classic market share literature that focuses on tradable goods (see for example Cheptea et al. 2005), the value added indicators used in this study are constructed to encompass all industries exposed to international competition within manufacturing global value chains. Our data take into account tradable goods but also services used to produce the manufacturing output and which are exposed to international competition, directly or indirectly. Indeed, the definition of tradable output subject to international competition is relatively clear in the case of gross exports of goods and, to a lesser extent, services. But the concept is more difficult to define when analysing activities or tasks used to produce these tradable goods. Some services produced locally and not traded internationally may be indirectly subject to international competition because used as input by exporters. To overcome this difficulty, we follow Timmer et al. (2013), and define the scope of activities subject to international competition as

\footnotetext{
${ }^{1}$ Figures encompass only the manufacturing part of the production process and exclude services (such as R\&D or marketing).

${ }^{2}$ We consider national firms as all resident firms in a given country.
} 
all activities employed, directly or indirectly, in the production to address manufacturing final demand. ${ }^{3}$

Our indicators are computed from the World Input-Output Database (WIOD), produced by a consortium of institutions and funded by the European Commission (see Timmer et al. 2015). The database merges national input-output tables with detailed international trade data to produce the world input-output tables, which break down the supply and use of each industry by all domestic or foreign industries and by final demand addressed. We are thus able to distinguish the value added produced domestically by each industry from the imported value added embedded in output and exports. Our method also enables to identify the geographical and sectorial origin of both domestic and imported value added.

The import content of exports increased over the last two decades following the development of global value chains. The paper shows that despite this trend, export market shares computed from value added trade flows do not substantially affect the basic diagnosis based on gross trade flows. Specially, emerging countries increased their export market shares at the expense of rich countries. Interestingly, analysing the manufacturing global value chain gives a rather mixed diagnosis. Considering all the tasks performed by services sectors within the manufacturing production chains reduces the gap in the dynamics of market shares indicators, especially between European countries. Particularly, French services industries largely contribute to the production to satisfy the manufacturing final demand, which is not considered while using manufacturing gross data. We thus confirm the findings of Demmou (2010), which stressed that the contraction of manufacturing industries in France between 1980 and 2007 is partly explained by the outsourcing of some industrial activities to services sectors. Yet, Germany stands at the opposite end of the spectrum: its good performance in manufacturing during the recent period relative to its GDP is mainly explained by a lower deformation towards services, comparing to other large countries.

Our results also show that the dynamics of market shares of most European countries within the manufacturing value chains converge if countries performance on their domestic markets in addition to their export performance - is taken into account. Thus our results highlight that there is no polarization of the manufacturing production within the European Union.

To understand these trends, we proceed to a first decomposition of the variation of our global market share indicator into four main components: countries' performance on exports and on their home markets; and the dynamics of foreign and domestic demands. The decomposition indicates a de-correlation between the export and domestic performances. Among the European countries in our sample; Spain and Germany, the two advanced economies that best maintain their export market shares between 1995 and 2011, do not reproduce this performance in their home markets. In contrast, for France and Italy, the loss of market shares is less pronounced in their home markets than in exports.

\footnotetext{
${ }^{3}$ See Bernard and Fort (2013) and Bernard et al (2014) on the classification of businesses between the manufacturing and services sectors, and Le Saux et Vicard (2014) on the role of services in the manufacturing sectors cost competitiveness.
} 
This de-correlation between export and domestic performances seems to reflect greater specialization of domestic production within the manufacturing global value chain while final demand remains diversified. Indeed, we construct a specialization index within the manufacturing global value chains - from the weighted standard deviation of Balassa's specialization indicator - that confirms a trend towards specialization of the productive apparatus in all advanced economies towards a relatively smaller number of economic sectors (or tasks); and which is negatively correlated with the performance of firms on their home market.

Finally, we proceed to a second decomposition of market shares growth rate, as in Gaulier et al. (2013); which quantifies countries specific performances and determines the extent to which their external performances reflect their geographical or sectorial specializations and other country's specific determinants. The overall trend reported above is confirmed: countries' performances (mainly European) converge if their domestic markets are taken into account along with their export performances. German, Japanese and US geographical performance components are positive for exports and negative for their global performance (which includes the home markets), indicating that their domestic demand or the performance of national firms on their home markets negatively affects their sales relatively to the world average. The geographical specialization of the United Kingdom and Italy also indicate downward domestic markets. Conversely, French and Spanish domestic markets are relatively upward and improve their overall performance. The decomposition is also performed with data on volume traded, i.e. adjusted for price fluctuations. Japan improves strongly performances in real terms whereas the German global performance worsens mainly because its weak domestic demand is more pronounced in real than in nominal terms. For France, both export and global relative performances improve; while the Spanish performance strongly deteriorates.

The paper is organized as follows. The next section presents the main trends observed in global value chains since 1995 and their impact on the foreign content of exports and on export market share indicators. Section 2 analyzes the manufacturing global value chains, which integrates all the tasks within the manufacturing production to address final demand. Section 3 introduces our indicator of global market share that takes into account both domestic and foreign demands. The section also performs a decomposition of the global indicator; as well as an analysis of the sectorial specialization within the manufacturing value chains. Section 4 proceeds to a second decomposition of market shares growth rate to identify the role played by three specific factors in the dynamics observed. The last section concludes. 


\section{Rise of global value chains and export market shares}

\section{a. Trade in value added: computation method}

Statistics in value added isolate the import content of output and give a measure of the domestic value added content in exports. It is thus a key indicator to analyze the participation of a country in world trade. The value added indicators are computed from the WIOD database (Timmer et al. 2015). This database consists of international input-output tables (IIOT) drawn from harmonised national input-output tables (IOT) of 40 countries, plus one observation from residues for the rest of the world, and for 35 industries over the period from 1995 to 2011 (see details in Appendix 1). Data are constructed by aggregating national IOT from national accounts with detailed international trade statistics. To ensure overall consistency, adjustments are made particularly to import and export data. The use of imports as intermediate consumption can therefore be measured by broad industry and country of origin. WIOD nonetheless maintain the assumption of proportionality between producers in the use of imported inputs within a single national industry (the hypothesis assumes that each producer has the same production function whether the producer is open to international trade or not). For more detail, see Timmer (2012). The international trade data is drawn from supply and use tables (SUTs) and converted into bilateral trade flows using coefficients computed from Comtrade and UN-ServiceTrade data for trade in goods and services, respectively.

In WIOD, changes in inventories are allocated to national trade flows but not international trade, which produces some negative values for national value added flows if data are disaggregated. These implausible values disappear when the data is aggregated. Nonetheless, we have chosen to exclude changes in inventories before calculating the flows contributing to manufacturing final demand (see next section), since the analysis is performed on the data at the industry level. The aggregate results do not change significantly when changes in inventories are excluded.

The computation method for the value added indicators draws on the basic IOT equation, which gives the following relationship between producers and consumers:

$$
x=A x+f=L_{f} f
$$

where $x$ is the vector $(\mathrm{i} * \mathrm{k}, 1)$ of global output of country $i$ industry $k ; A$ is the matrix $\left(i^{*} k\right.$, $\left.i^{*} k\right)$ of technical factors and $\mathrm{f}$ the vector $(\mathrm{i} * \mathrm{k}, 1)$ of final demand. The second part of the equation uses the Leontief matrix $(i * k, i * k)$, with $L_{f}=(I-A)^{-1}$.

Using this methodological framework with WIOD tables and a vector $(1, \mathrm{i} * \mathrm{k})$ of industries' value added enables to compute the domestic value added contained in trade flows. These flows can be further refined to obtain the industrial origin of the value added. However, this origin is disassociated from the gross data as the industrial value added is either exported 
directly (by the industry itself) or indirectly (embedded in the gross exports of other industries). Moreover, the indicator measures final destination of the value added traded, unlike traditional trade data that measure the immediate destination (for more details of the method, see Stehrer,2013; or Koopman et al. 2014).

\section{b. The development of global value chains increases the import content of exports}

The import content of exports surged between 1995 and 2008 as world gross exports rose faster than the domestic value added actually exported. This pattern is mainly explained by the development of the global value chains (GVC) and the international fragmentation of production, which increases the exports of intermediate goods and services. Over this period, the ratio of gross exports on the domestic value added exported increases from $127 \%$ to $142 \%$ (see Chart 2). After a drop in 2009 following the great financial crisis, the world trade slowly recovers and the ratio stands at $136 \%$ in 2011. Furthermore, the gap between gross and value added exports is higher when focusing on manufacturing exports. Indeed, production process within manufacturing industries is highly verticalized as their production chains are more fragmented. Consequently, gross exports are twice higher than the domestic value added exported for these industries in 1995 and 2.45 times higher in 2008.

\section{Chart 2: World gross to value added ratio for total exports (left panel) and manufacturing exports (right panel)}

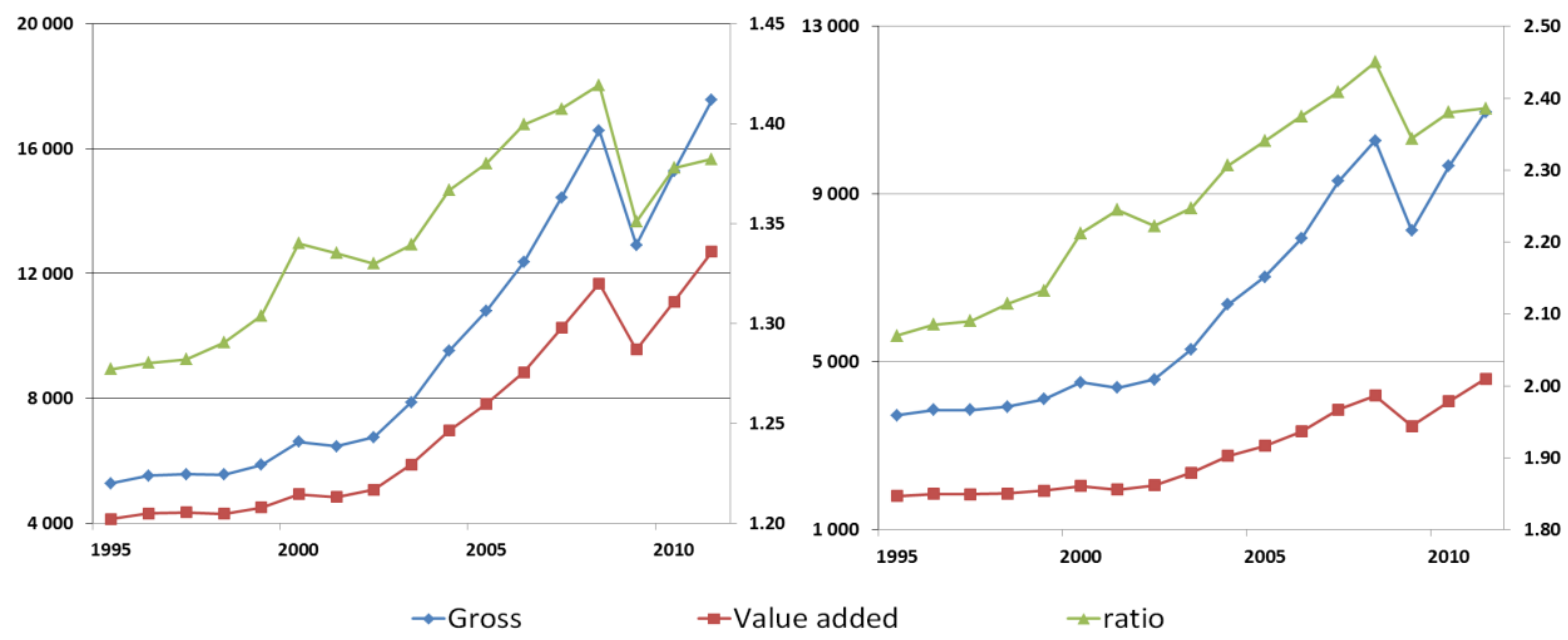

Source: WIOD and authors' calculations.

Note: Billions of current US\$, ratios of gross on value added for each chart on the right scale

The import content of world exports, i.e. the share of foreign value added in word exports, rose by approximately 6 percentage points over the seventeen years of the data, from $19 \%$ in 1995 to $25 \%$ in 2011 (see Chart 3). This trend concerns almost all countries. In France, the 
import content of exports rose by 9 points since 1995 and stands at $29 \%$ in 2011. Germany has a similar evolution (+10.5 points) as well as Spain (+10) and Italy (+9). However, significant differences are observed between countries, even in Europe. Several underlying factors can be advanced. Countries with relatively small economic and population size normally incorporate more foreign content on their output because their domestic value chains are less diversified (like Austria or Belgium). Conversely, major economies (United-States, Japan or China) add proportionately more domestic value added to their exports. Geography and economic specialization are also determining factors. Geographically isolated countries, big commodity exporters (Russia, Brazil or Australia) or services exporters (United Kingdom) incorporate relatively less imported value added to their exports.

\section{Chart 3: Import content of exports (\% of gross exports)}

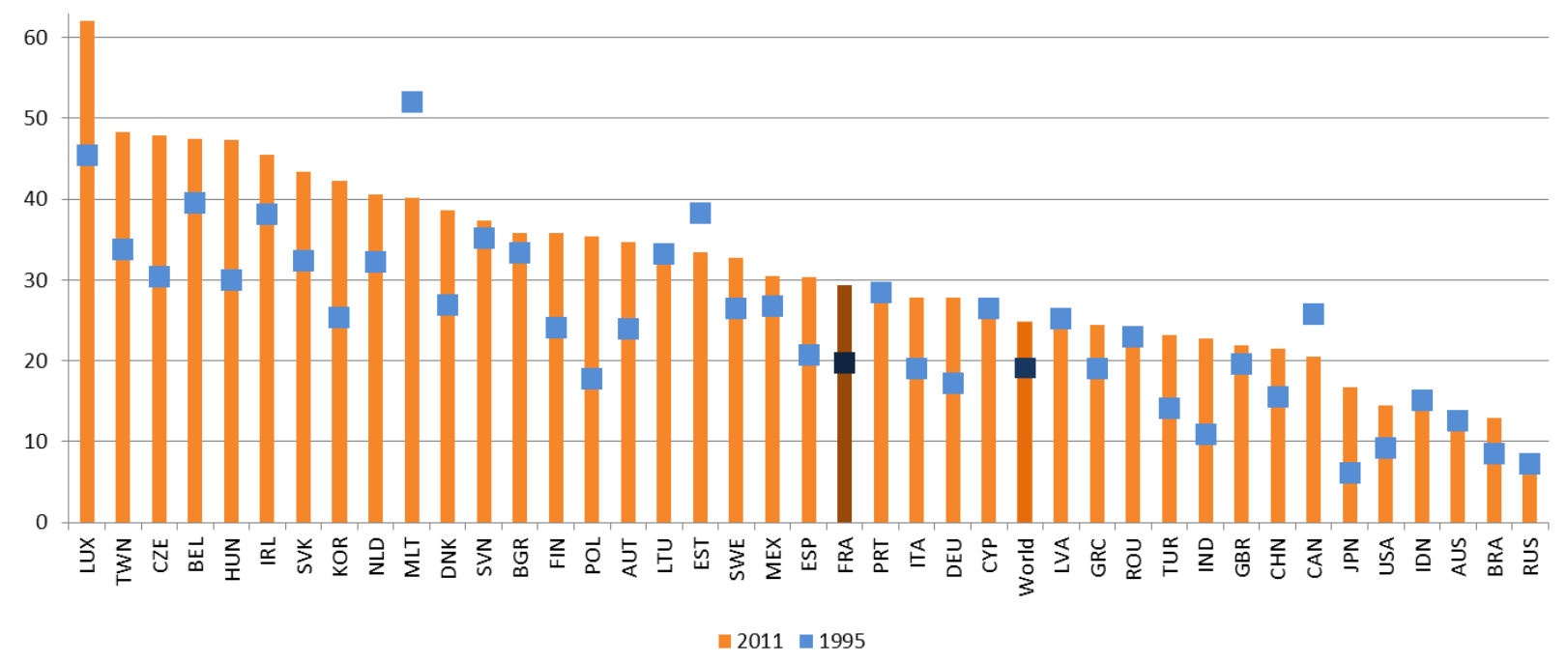

Source: WIOD and authors' calculations.

Moreover, the relatively high import content of European exports in general suggests that the hypothesis of a "bazaar economy", put forward by Sinn (2005), is not specific to Germany. It highlights that the strong rise of trade within the European Union went along with the development of a production network between the member states (regionalism). The European import content of exports increased almost twice faster than the world average (9 points in the European Union and 5 points in the World average), reaching one third of the European Union exports in 2011; while the world average equals one quarter of world exports (respectively $32.6 \%$ and $25.8 \%$ ).

\section{c. Value added and gross market shares}

Most major rich countries have experienced an erosion of their export market shares as measured by gross exports over the period between 1995 and 2011 (see Chart 4). This weak performance is mainly explained by the strong growth of output and exports of emerging 
economies, especially China in the 2000s ( $+272 \%$ between 1995 and 2011, and $+180 \%$ since 2000). However, Spain, and to a lesser extent Germany, are atypical because they experienced a relative limited change in their export performance (+ $5 \%$ and $-18 \%$ respectively). In contrast, export market shares decline are pronounced in the United States (-28\%), United Kingdom (-31\%), Italy (-33\%), France (-40\%) and Japan (-45\%).

This diagnosis is not essentially changed if trade is measured in value added. The major emerging countries also experience a strong growth of their exports measured with these indicators, like China (+ 272\%), India (+125\%), Russia (89\%) or Brazil $(+60 \%)$. This trend in the world economy reduces the market shares of the rich countries as for Japan $(-47 \%)$, France $(-42 \%)$, Italy $(-35 \%)$, United Kingdom (-27\%), for the United States $(-25 \%)$ and Germany (-23\%). As well as for gross data, Spain (-1\%) is the sole exception among the rich countries and resist better.

\section{Chart 4: Gross and value added market share of High income countries}

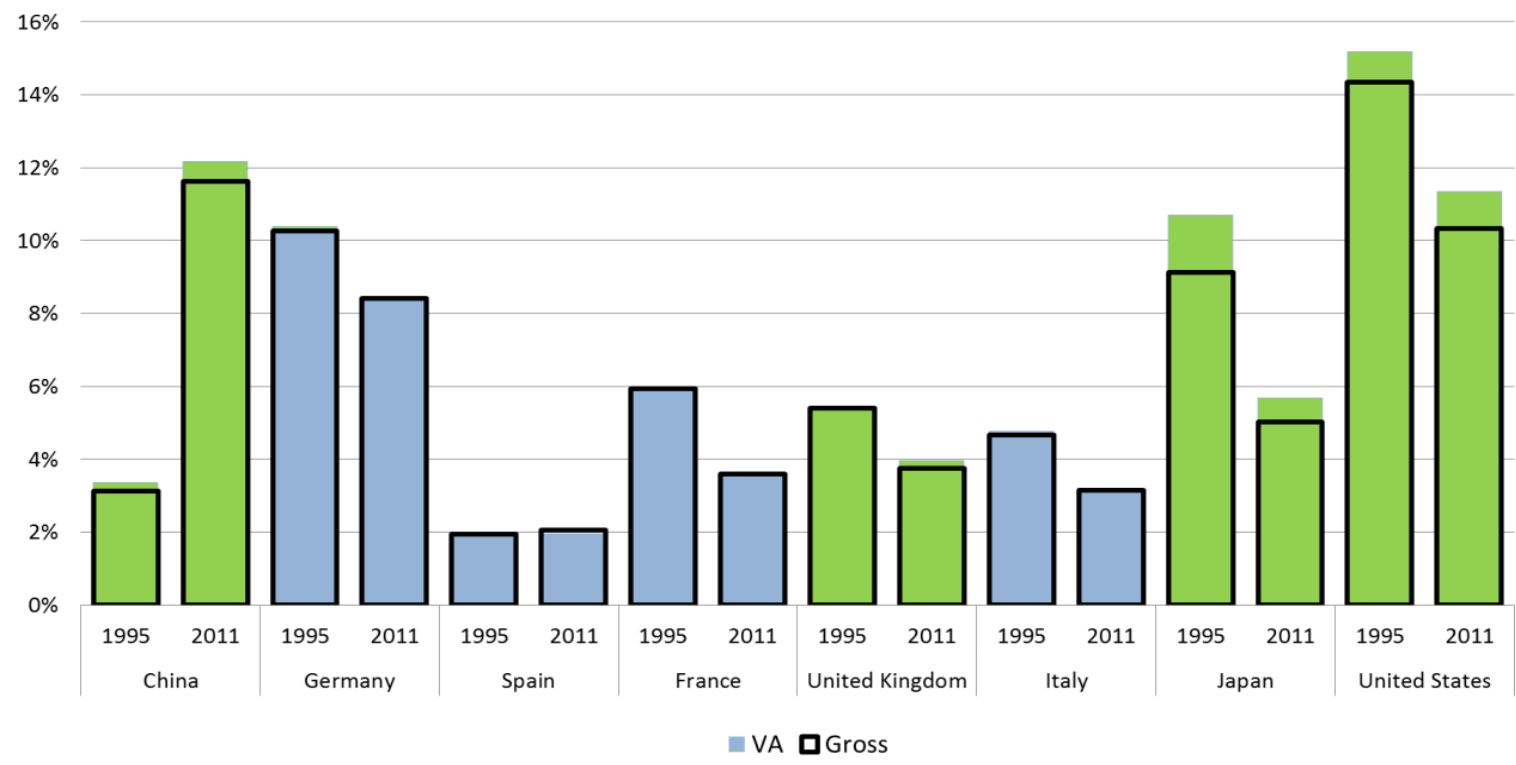

Source: WIOD and authors' calculations.

The right panels of Chart 5 show that the ratios of market share of gross on value added flows in total exports (top panel) and in manufacturing exports (bottom panel) are relatively stable through the period. Total export performance deteriorates strongly in value added compared to gross exports for all countries, except for the United States and United Kingdom; and especially for China, Germany and Spain. However, regarding manufacturing exports, China performs better with value added data, as well as the United States and United Kingdom. The other countries experience a decline in their manufacturing market shares in value added, which is more pronounced for Germany and France. Nonetheless, the overall diagnosis of decrease in rich countries' market shares changes only marginally (see chart 5 , left panel). In general, countries with a domestic content in total exports higher than the world average $(75 \%$ in 2011) increase their market shares when measured in value added compared to gross data; 
while it is the opposite for countries with a domestic content in total exports lower than the world average.

\section{Chart 5: Export market shares in value added trade flows ${ }^{4}$}
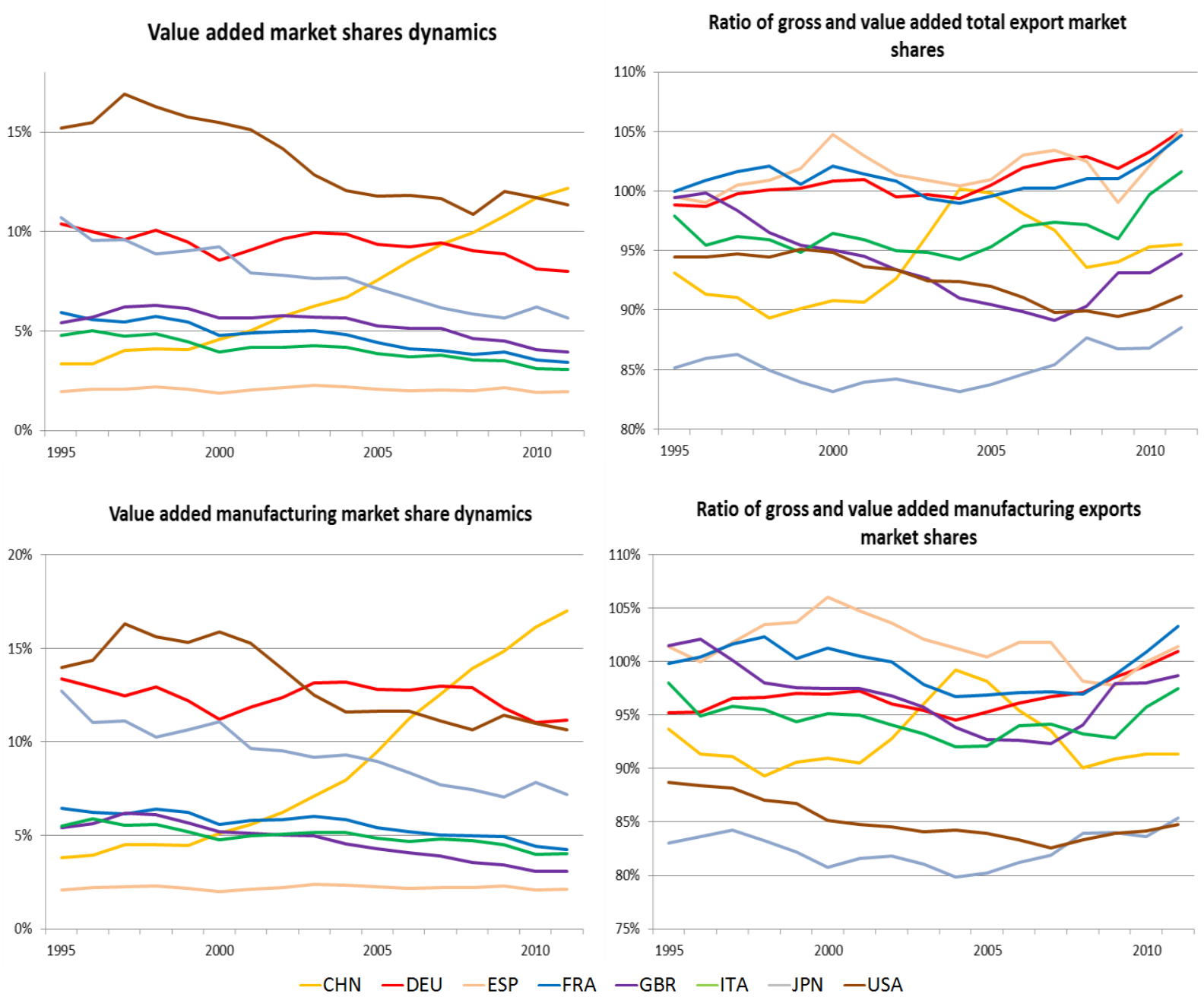

Source: WIOD and authors' calculations.

For China, the ratio of the gross exports to value added exports follows a singular tendency (Chart 5, right panel). Until the 2000's the indicator is low, stressing a relative closure to global value chains. But few years later, until the mid-2000's, the indicator increases quickly and China reaches the same level as in the Eurozone countries. As from 2005, nonetheless, the indicator decreases and reaches the average level of the sample before stabilizing after 2007. Yet, the normalization of the international trade insertion of China began prematurely ${ }^{5}$ (see Lemoine et Unal, 2012 and 2015). These developments suggest that the idea of China as the "world factory", assembling intermediary goods in order to overflow foreign markets with

\footnotetext{
${ }_{5}^{4}$ Average annual growth rate are in appendix (table A1 and table A2)

${ }^{5}$ Global Chinese trade surplus started to decrease in 2007 despite an important surplus with the United States and the EU.
} 
low domestic value added, is only reliable during a short period. However, these results should be considered with caution as they do not take into account the distinction between processing or non-processing exports. Thereby Chen et al. (2012) find that the domestic value added of processing exports in China is much lower than that of non-processing exports; whereas Koopman et al. (2012) stress that the import content of exports is twice higher in processing exports, because of the high level of foreign value added incorporated in this kind of activity. Furthermore, international IOT do not distinguish between exporting and nonexporting firms such that the domestic content of exports is the same as for domestic trade. Thus, for exporting firms, the ratio is normally over evaluated (Timmer, 2012). Besides, Kee and Tang (2016) show, from firm level data, that the domestic content of Chinese exports increases with the development of its own national supply chain.

\section{Value added within the manufacturing global value chains}

\section{a. Domestic value added to satisfy manufacturing final demand}

The output linked to international production chains can be broken down in order to take into account, for a given country, all jobs, tasks and value added directly and indirectly involved in the production of final manufactured goods (Timmer et al. 2013). Yet, this breakdown enables to identify all tasks involved within the manufacturing production chains, whatever its sectorial origin ${ }^{6}$. Chart 6 presents a schematic example of the value added produced to address the manufacturing final demand. These activities are those most likely to contribute to the international fragmentation of production and to be confronted to international competition, directly or indirectly (as they can be employed as input by other national industries). The weight of these activities in GDP is larger than that of the manufacturing industry on its own; and includes in particular all the activities outsourced to services firms or to raw material industries. The manufacturing GVC income (Timmer et al. 2013) is thus defined as the total income produced within the manufacturing global value chains, and equals the total value added produced to satisfy the manufacturing final demand (VAMFD).

From WIOD, the domestic value added exported by country i industry $\mathrm{k}$ and absorbed by the world final demand for industry $k^{\prime}$ (in the study $k^{\prime}$ is all the manufacturing industries, except "Coke, Refined Petroleum and Nuclear Fuel") is computed from the following equation:

$$
D V A X D F_{i k, k^{\prime}}=v_{i k} L_{f} f^{k^{\prime}}
$$

\footnotetext{
${ }^{6}$ Our definition of manufacturing sector excludes the industry of "Coke, Refined Petroleum and Nuclear Fuel" for which variations in raw materials prices are likely to have a predominant impact on value added.
} 
with $v_{i k}$ the vector of value added of country $\mathrm{i}$ industry $\mathrm{k}$ and $f_{k^{\prime}}$ is the world final demand for industry $k^{\prime}$ (including the demand of the exporting country i). The indicator can be used to measure bilateral flows or domestic trade by transforming the vector of final demand. For domestic trade flows, the sum of the domestic value added to meet the domestic and world final demands equals the domestic GDP.

\section{Chart 6: Value added produced to address the manufacturing final demand}

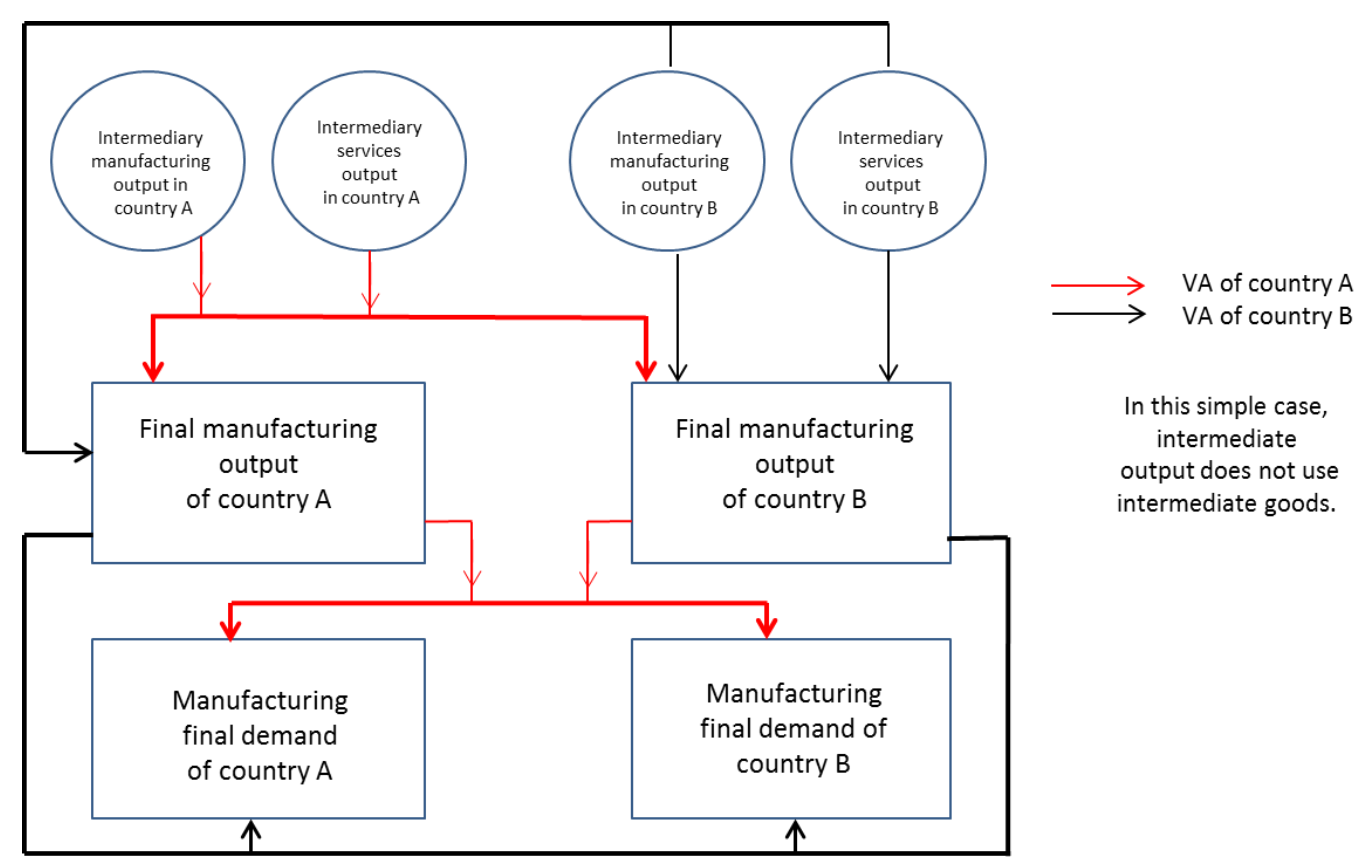

\section{b. Value added for the manufacturing final demand and the role of services in the manufacturing value chains}

Identifying all activities linked to the production of manufacturing goods based on final demand allows considering all the value added employed, regardless of the industry of origin. With the development of global value chains, rich countries specialized much on services tasks within the manufacturing chains, like research and development or other business services (see Cezar, 2016a, for the case of France). These tasks are not recorded as manufactured production by national accounts, but they are however responsible for and capture a large share of manufacturing total value added (Timmer et al. 2014). Therefore, analyzing all activities within manufacturing value chains has become an important issue to understand the role of countries within these manufacturing chains. Furthermore, taking into account all these activities within GVC, especially services, has become almost unavoidableto better assess the international performance of rich countries. An analysis of export market shares with these data and of the differences with traditional manufacturing export data is performed in the Appendix 2 of the paper. 


\section{Chart 7: Share of value added for the manufacturing final demand on total value added exported (left panel) and on GDP (right panel)}

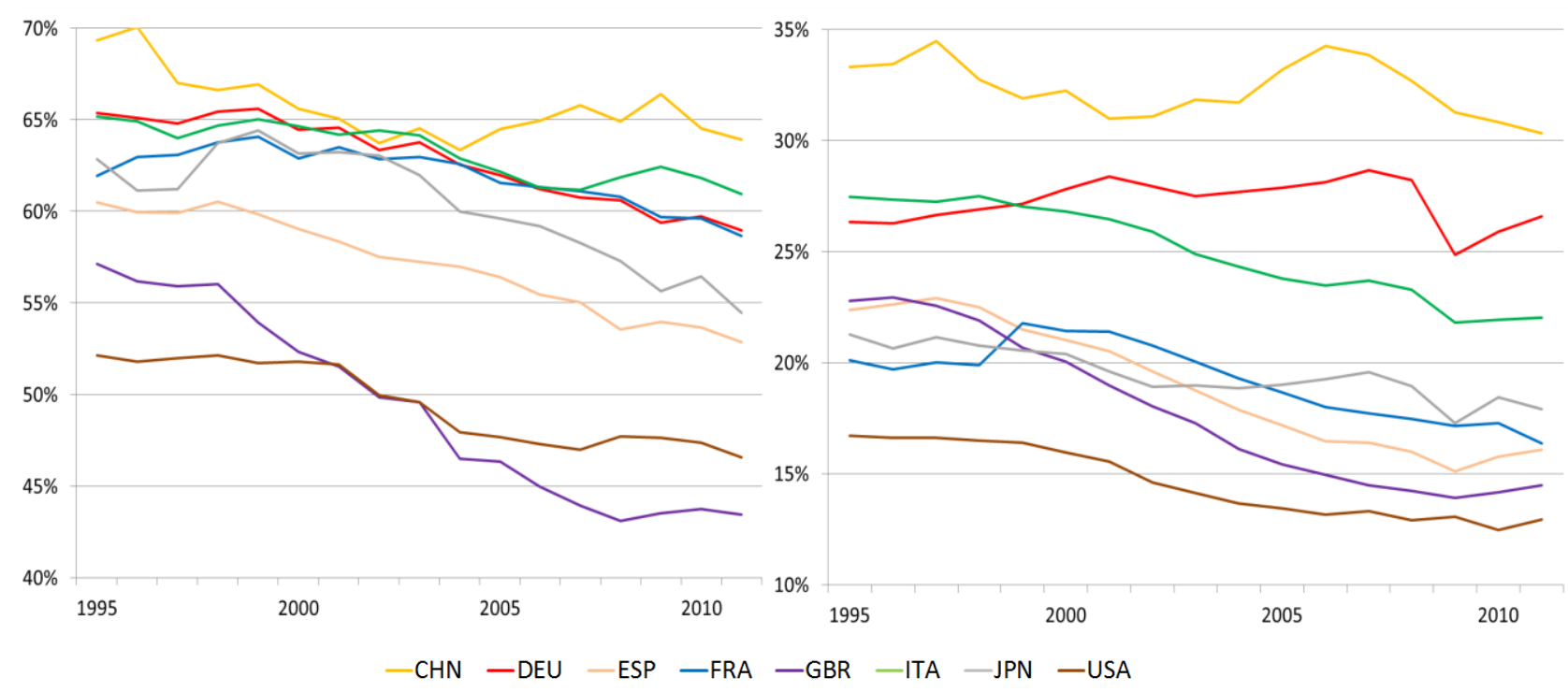

Source: WIOD and authors' calculations.

Note: GDP is computed from WIOD tables as the sum of total domestic value added produced to satisfy total final demand addressed to the country (domestic and foreign)

In 2011, the output for the manufacturing final demand remains high in China and Germany (respectively $30 \%$ and $27 \%$ of their GDP, see Chart 7) and, to a lesser degree, in Italy (22\%); it is lower in Japan (18\%), France (16\%), Spain (16\%), United Kingdom (14\%) and United States $(13 \%)$. The share of the manufacturing value chains in the GDP decreases since 1995 for almost all countries, especially in Spain and in the United Kingdom (-2\% and $-2.8 \%$ on average per year). Japan, France and Italia follow a similar dynamic (-1.1\%, $-1.3 \%$ and $-1.4 \%$ per year). Yet, the downward trend in France started a little later, after a short rise up to $22 \%$ of its GDP in 1999. In contrast, the trend in Germany and China are different. For the former, the share of the manufacturing output in GDP increases by $0,1 \%$ per year between 1995 and 2011. Germany performs nevertheless better before the great financial crisis, with an average annual growth rate of $1.7 \%$ until 2007. From 1995 to 2007, Chinese VAMFD rose by an annual pace of $0.4 \%$ despite an overall decrease during the whole period.

Table 1: Share of value added for the manufacturing final demand in exports and GDP (Average annual growth rate, 1995 to 2011).

\begin{tabular}{lcccccccc}
\hline & China & Germany & Spain & France & $\begin{array}{c}\text { United } \\
\text { Kingdom }\end{array}$ & Italy & Japan & USA \\
\hline In exports & $-0.5 \%$ & $-0.6 \%$ & $-0.8 \%$ & $-0.3 \%$ & $-1.7 \%$ & $-0.4 \%$ & $-0.9 \%$ & $-0.7 \%$ \\
In GDP & $-0.6 \%$ & $0.1 \%$ & $-2.0 \%$ & $-1.3 \%$ & $-2.8 \%$ & $-1.4 \%$ & $-1.1 \%$ & $-1.6 \%$ \\
\hline
\end{tabular}

Source: WIOD and authors' calculations. 
The share of the output for manufacturing final demand in exports is much higher than in GDP, and varies between $65 \%$ in China to $44 \%$ in the United Kingdom. Furthermore, the downward trend of the share of this output in exports is lower than in GDP, except in Germany. The decrease of value added for manufacturing final demand is strong in the United Kingdom and Japan. Both countries tackle a sharp decline on annual average of respectively $1.7 \%$ and $-0.9 \%$ between 1995 and 2011 (see Table 1). The output for manufacturing in Chinese exports drops until 2003 and then stabilizes. In the Euro area, the VAMFD in Spanish exports deteriorates from $60.5 \%$ to $52.9 \%$ (-0.8\% per year). In contrast, France, Italia and Germany resist better, and their average annual growth rates are respectively of $-0.3 \%$, $0.4 \%$ and $-0.6 \%$. Among the eight countries in our sample, France has the best performance, which is greatly due to its services sectors used on its manufacturing production chains.

Table 2: Decomposition of value added within the manufacturing global value chain (average annual growth rate in current US dollars, 1995-2011)

\begin{tabular}{|c|c|c|c|c|c|c|}
\hline \multirow{3}{*}{ Country } & \multirow{2}{*}{\multicolumn{2}{|c|}{$\begin{array}{c}\text { VAMFD } \\
\text { Share of GDP }\end{array}$}} & \multirow{3}{*}{\multicolumn{2}{|c|}{$\begin{array}{c}\text { VAMFD GDP } \\
\text { current US dollars } \\
\text { AAGR }\end{array}$}} & \multicolumn{2}{|c|}{ VAMFD from } \\
\hline & & & & & Services & Manuf. \\
\hline & 1995 & 2011 & & & \multicolumn{2}{|c|}{ AAGR } \\
\hline China & 33 & 30 & 14.8 & 15.5 & 16.2 & 14.8 \\
\hline Germany & 26 & 27 & 2.3 & 2.3 & 3.0 & 2.1 \\
\hline Spain & 22 & 16 & 3.7 & 5.9 & 5.1 & 3.1 \\
\hline France & 20 & 16 & 2.4 & 3.7 & 3.6 & 1.4 \\
\hline United Kingdom & 23 & 14 & 1.8 & 4.8 & 3.6 & 0.7 \\
\hline Italy & 27 & 22 & 2.8 & 4.3 & 4.0 & 2.2 \\
\hline Japan & 21 & 18 & -0.4 & 0.7 & 0.2 & -0.7 \\
\hline United States & 17 & 13 & 2.9 & 4.5 & 2.8 & 2.7 \\
\hline
\end{tabular}

Source: WIOD and authors' calculations.

Note: VAMFD is the value added for manufacturing final demand; and AAGR is the Average annual growth rate.

The output generated to address the manufacturing final demand increase in all countries except in Japan in current dollars. The growth rate remains lower than the GDP growth, resulting in a decrease of its weight in GDP between 1995 and 2011. This trend reflects nonetheless divergences in underlying dynamics: for Japan and Germany, the weak growth of their GDP over the period largely explains the resistance of the output to meet the manufacturing final demand as share of GDP (see columns 3 and 4 of Table 2). Although growth in income from the manufacturing value chain is the same in France and Germany; the stronger growth rate of French GDP results in a 4 percentage points drop in the share of the manufacturing income reported to GDP in France (from 20\% of GDP in 1995 to $16 \%$ in 2011 ) compared to a virtually stable share in Germany (from $26 \%$ to $27 \%$ ).

Within the manufacturing output, the value added generated by services industries in rich countries underlines their importance in the production process and the specialization of advanced economies in these industries. The share of value added generated by domestic services industries has systematically increased faster than that generated by manufacturing 
industries (see columns 5 and 6 of Table 2). However, this trend is not uniform among all countries.

\section{Chart 8: Share of services within the manufacturing value chain (\% total value added for manufacturing final demand)}

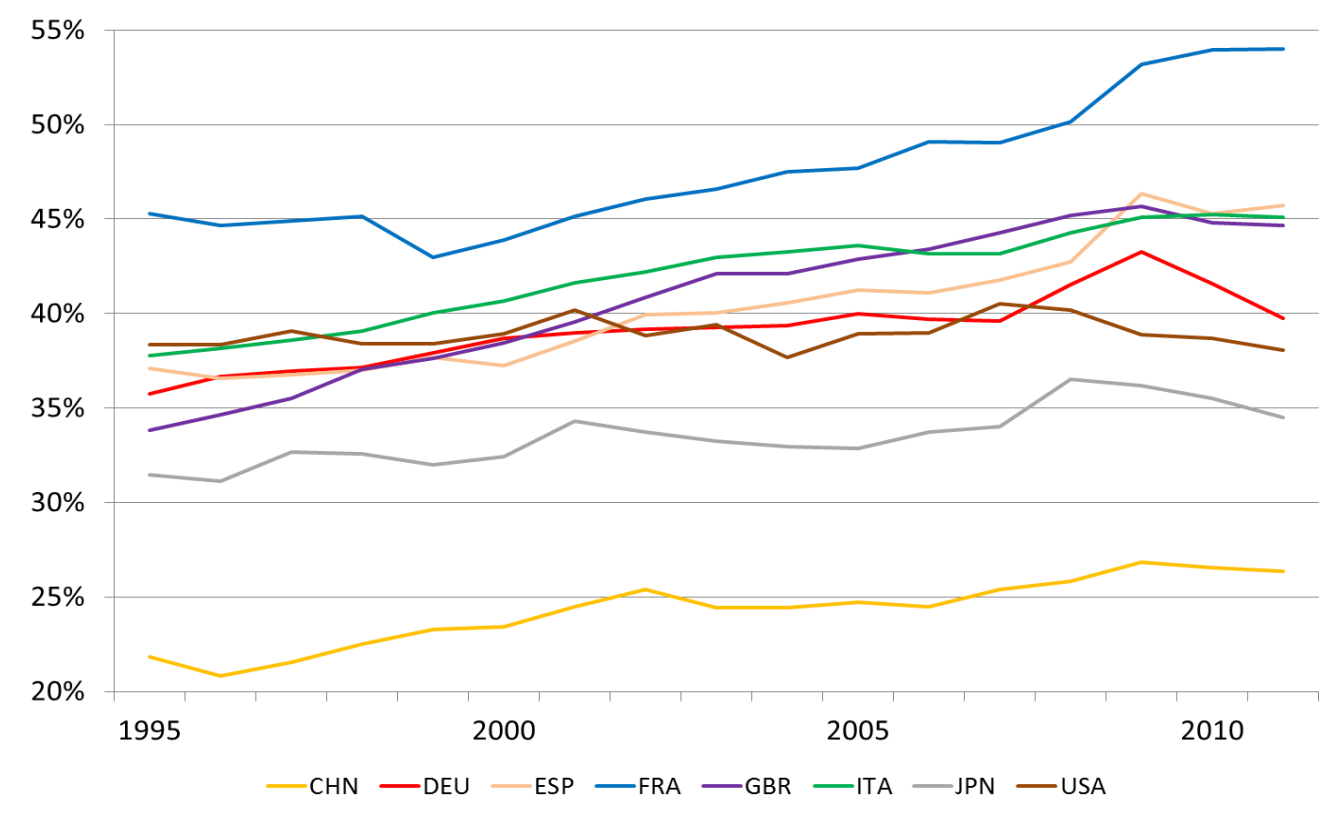

Source: WIOD and authors' calculations.

In our sample, France is the country where the manufacturing production chains are the most dependent on the services sectors. The share of these sectors on total valued added produced to address the manufacturing final demand strongly increases in this country since 1995, exceeding 50\% in 2008 to stand at 54\% in 2011 (see chart 8). This trend is mostly explained by a faster growth rate in the value added from services sectors (with an average annual growth of 3.6\% between 1995 and 2011) than in the manufacturing industries (1.4\%). Meanwhile the development of the German manufacturing value chains faces a lower deformation towards services, with a lower gap between both growth rates (respectively 3\% and 2.1\%).The others European countries are also dependent on services for their manufacturing value chains. Value added from these sectors represents around $45 \%$ of VAMFD in Italy, Spain and the United Kingdom. Furthermore, the weight of services in VAMFD stagnates in the United States $(0 \%)$, mainly due to a close growth rate between services and manufactures $(2.8 \%$ and $2.7 \%)$; and slowly increases in Japan $(0.6 \%)$ over the period. China is the less dependent country on services sectors for its manufacturing value chains among the sample ( $25 \%$ of total production to address final demand), despite a growth rate much higher than in the other countries $(+16.2 \%$ per year on average).

Considering all activities involved in the production of manufacturing goods seems essential when comparing trends in industrial bases between economies. Based on the sole criteria of the manufacturing sector, Germany records stronger income growth than France over the 
period from 1995 to 2011 (+ 39\% against $+25 \%)$, whereas income growth within the manufacturing value chains is similar when all the domestic activities linked to the manufacture production are taken into account ( $+45 \%$ and $+47 \%$ respectively).

\section{Global market shares: export and domestic performances}

\section{a. Global market shares}

The home market, which is generally the leading market for national firms, is another parameter for analyzing the competitiveness and dynamism of the domestic firms. Furthermore, the national market of a given country influences the exports of its trade partners, and divergences in national demand dynamics are reflected in the export performances of trade partners. Statistics of trade in value added enable to compute each country's market shares in the world manufacturing final demand, including foreign and domestic demands. This global market share is based on the manufacturing world final consumption and therefore includes all the activities used in the production, whether the value added comes from manufacturing or services industries; and whether the demand is foreign or domestic. Moreover, as the global market shares encompass both foreign and home markets, it enables to bypass the issue concerning the heterogeneity of countries' production function between the import content of exporting firms and firms producing only for their home market, especially for China (for the case of France, see Cezar, 2016b).

Table 3: Global market shares (average annual growth rate)

\begin{tabular}{lcccccccc}
\hline & China & Germany & Spain & France & $\begin{array}{c}\text { United } \\
\text { Kingdom }\end{array}$ & Italy & Japan & $\begin{array}{c}\text { United } \\
\text { States }\end{array}$ \\
\hline $\mathbf{1 9 9 5 - 2 0 1 1}$ & $9.6 \%$ & $-2.3 \%$ & $-0.9 \%$ & $-2.2 \%$ & $-2.8 \%$ & $-1.8 \%$ & $-4.9 \%$ & $-1.8 \%$ \\
\hline $\mathbf{2 0 0 7 - 2 0 1 1}$ & $10.4 \%$ & $-5.2 \%$ & $-4.7 \%$ & $-5.6 \%$ & $-9.1 \%$ & $-6.4 \%$ & $-0.3 \%$ & $-4.6 \%$ \\
$\mathbf{2 0 0 0 - 2 0 0 7}$ & $9.8 \%$ & $1.7 \%$ & $2.7 \%$ & $0.2 \%$ & $-1.9 \%$ & $1.0 \%$ & $-8.0 \%$ & $-4.2 \%$ \\
$\mathbf{1 9 9 5 - 2 0 0 0}$ & $8.9 \%$ & $-5.3 \%$ & $-2.9 \%$ & $-2.8 \%$ & $1.4 \%$ & $-1.9 \%$ & $-4.0 \%$ & $4.2 \%$ \\
\hline
\end{tabular}

Source: WIOD and authors' calculations.

Considering the home markets does not change the downward trend in market shares of high income countries, which have dwindled in favor of emerging countries, especially China (Chart 9). The switch is nonetheless dampened with the global market shares indicator. China's share of world production within the manufacturing value chain has grown fourfold since 1995, positioning the country as the world leading producer in 2011 with $17.6 \%$ of 
market shares, ahead of the United States with $14.9 \%$. The loss of market shares recorded by the major advanced economies is particularly pronounced between 2007 and 2011, with more contrasted performances over the other periods (particularly the early 2000s), mainly on their home markets.

\section{Chart 9: Global market shares from value added for manufacturing final demand}

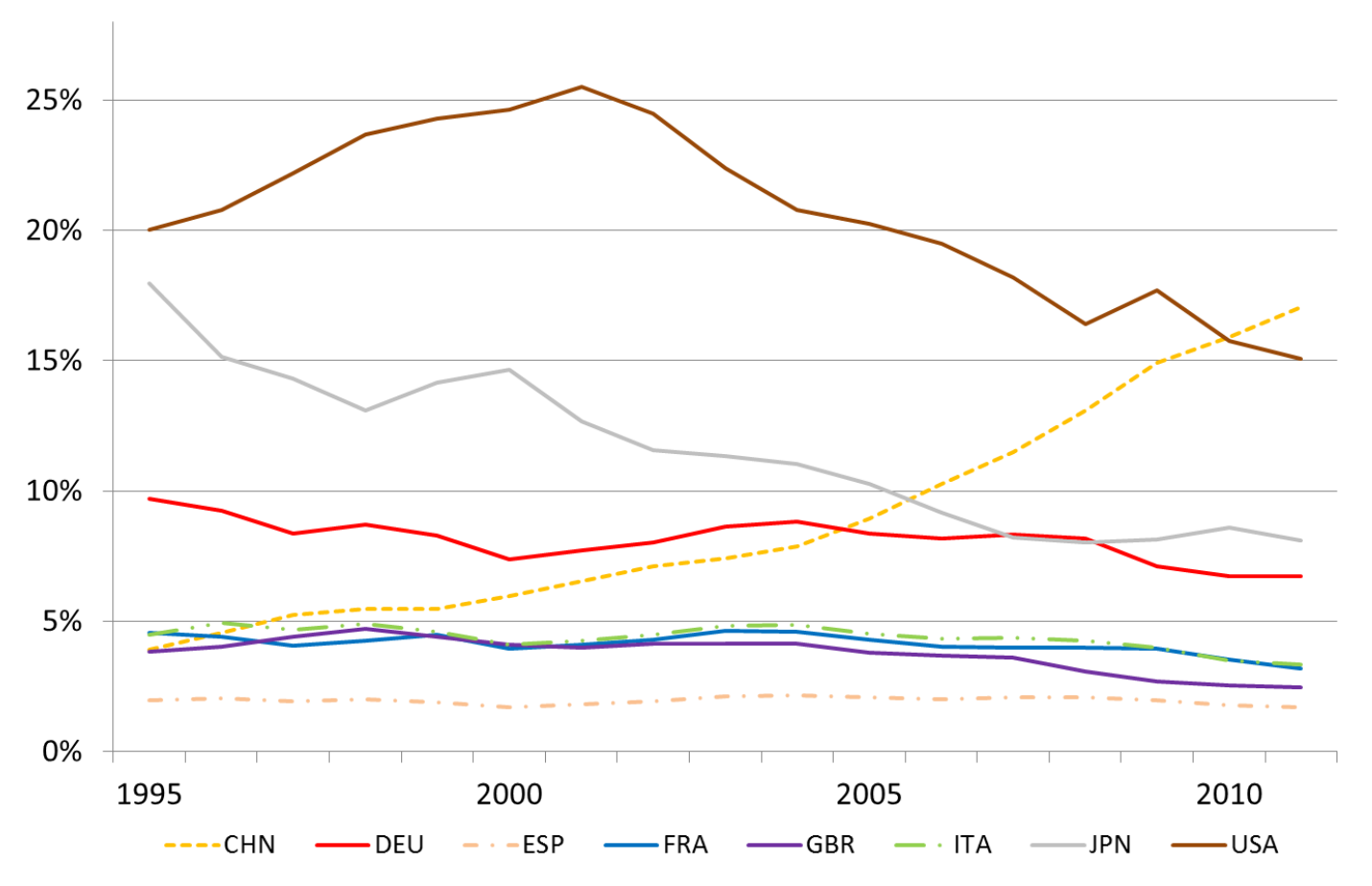

Source: WIOD and authors' calculations.

Table 3 shows the average annual growth rate of countries share of the world manufacturing final demand, for different periods. Between 1995 and 2011, taking into account the value added supplied to home markets results in significantly different relative trends compared with those obtained based solely on export performances. The global market shares of three countries - Japan, Germany and Spain - deteriorate faster than their export market shares. Spain, despite this deterioration, shows a better global performance with stronger resilience than other large countries; whereas Japan declines sharply, with its market shares dropping by half ${ }^{7}$. Germany performs in line with other large European countries, whose market shares diminish at an average pace of $2 \%$ to $3 \%$ a year. France shows a similar performance: both countries record the same trends in global market shares, stronger than that of the United Kingdom but weaker than those of Italy and the United States. From 2000-2007, when the euro appreciated, all the Eurozone countries increase their market shares in value, with

\footnotetext{
${ }^{7}$ Data is in current prices. The real depreciation of the Japanese yen resulting in particular from deflation in Japan can to a large extent explain Japan's "lag": Japan has lost international purchasing power and its terms of trade have deteriorated.
} 
Germany outperformed only by Spain. Whatever the period considered, the differences between the main Eurozone countries are relatively small.

Overall, taking into account countries' performance on their home markets - in addition to their export performance - makes the dynamics of market shares converge for most of European countries, except for Spain that outperforms among high income countries. These findings are at odds with a polarization of production for manufacturing GVCs within Europe, somewhat contrary to what is observed on gross exports.

\section{b. Decomposition of global market shares: performance and demand on export and home markets}

The global market share can be broken down into two main terms. For a country i, global market shares are decomposed as follows:

$$
\frac{V A_{i, W}}{V A_{W, W}}=\frac{V A_{i, i}}{V A_{W, i}} \times \frac{V A_{W, i}}{V A_{W, W}}+\frac{V A_{j, W X \nexists i}}{V A_{\sum_{j} W X, j \neq i}} \times \frac{V A_{\sum_{j} W X, j \neq i}}{V A_{W, W}}
$$

where $W$ indicates all countries in the world and $W X$ the final demand met by foreign output. The first term in the Equation represents the activities that serve the country's domestic final demand, and consists of two components: the market share of country $i$ in its own home market multiplied by the share of its home market in the world manufacturing final demand. The second term reflects the performance in foreign markets and is defined as the country i's export market shares multiplied by the world openness ratio (ratio between total exports and total output, excluding country i's market). Table 4 shows each element of this decomposition. 
Table 4: Contribution of national and foreign markets to changes in global market shares

\begin{tabular}{|c|c|c|c|c|c|c|c|c|c|}
\hline & & China & Germany & Spain & France & $\begin{array}{c}\text { United } \\
\text { Kingdom }\end{array}$ & Italy & Japan & $\begin{array}{l}\text { United } \\
\text { States } \\
\end{array}$ \\
\hline \multicolumn{10}{|c|}{2011} \\
\hline$A=B^{*} C+D * E$ & Total market share & $17,1 \%$ & $6,7 \%$ & $1,7 \%$ & $3,2 \%$ & $2,5 \%$ & $3,4 \%$ & $8,1 \%$ & $15,1 \%$ \\
\hline B & Domestic performance & $69,4 \%$ & $36,6 \%$ & $39,5 \%$ & $36,0 \%$ & $29,3 \%$ & $47,1 \%$ & $66,7 \%$ & $56,3 \%$ \\
\hline c & Size of the domestic market & $13,6 \%$ & $5,8 \%$ & $1,8 \%$ & $3,4 \%$ & $2,7 \%$ & $3,2 \%$ & $7,6 \%$ & $17,6 \%$ \\
\hline D & Export performance & $17,1 \%$ & $10,3 \%$ & $2,1 \%$ & $4,2 \%$ & $3,6 \%$ & $3,9 \%$ & $6,6 \%$ & $12,6 \%$ \\
\hline $\mathrm{E}$ & Adjusted world exports & $44,6 \%$ & $45,1 \%$ & $47,6 \%$ & $46,5 \%$ & $46,8 \%$ & $47,0 \%$ & $46,2 \%$ & $41,0 \%$ \\
\hline \multicolumn{10}{|c|}{1995} \\
\hline$A=B^{*} C+D * E$ & Total market share & $3,9 \%$ & $9,7 \%$ & $2,0 \%$ & $4,6 \%$ & $3,9 \%$ & $4,5 \%$ & $18,0 \%$ & $20,0 \%$ \\
\hline B & Domestic performance & $71,2 \%$ & $58,5 \%$ & $57,4 \%$ & $50,6 \%$ & $47,5 \%$ & $60,5 \%$ & $83,2 \%$ & $68,6 \%$ \\
\hline c & Size of the domestic market & $3,3 \%$ & $8,9 \%$ & $2,1 \%$ & $4,2 \%$ & $3,8 \%$ & $4,0 \%$ & $16,2 \%$ & $21,5 \%$ \\
\hline $\mathrm{D}$ & Export performance & $4,2 \%$ & $13,2 \%$ & $2,1 \%$ & $6,8 \%$ & $5,8 \%$ & $5,7 \%$ & $12,8 \%$ & $16,9 \%$ \\
\hline $\mathrm{E}$ & Adjusted world exports & $37,0 \%$ & $34,2 \%$ & $37,0 \%$ & $35,9 \%$ & $35,9 \%$ & $36,3 \%$ & $35,2 \%$ & $31,1 \%$ \\
\hline
\end{tabular}

Source: WIOD and authors' calculations.

For each country, the domestic final demand represents a large part of national firms' income; particularly in the three largest countries in the sample: China, Japan and the United States, where their domestic final demand accounts for respectively $69 \%, 67 \%$ and $56 \%$ of total value added produced in 2011. In Germany (37\%), United Kingdom (29\%), France (36\%), Spain (39\%) and Italy (47\%), foreign final demand remains the main market for their national manufacturing output ${ }^{8}$. The increasing importance of foreign demand in all major countries since 1995, from 14 (France) to 22 (Germany) percentage points, reflects the process of globalization and the resulting growing interdependence between economies.

These findings are strengthened when focusing on the relation between the relative size of countries' domestic demand (relative to the world) and their domestic market shares. Big economies, like the United States or China, hold an important part of their own home markets while most of the small economies (less than $2 \%$ of world demand), hold a lesser share. Chart 10 indicates that the relation between the two variables strengthens between 1995 and 2011. The reinforcement of globalization and the development of global production chains increase the interdependence among countries, particularly for small economies that are more dependents within the manufacturing global value chains; whereas large economies can rely more on their domestic value chains.

\footnotetext{
${ }^{8}$ This share would be greater than $50 \%$ if one considered that intra EU trade flows were domestic trade flows.
} 
Chart 10: Size of domestic markets and domestic market shares (1995 and 2011)

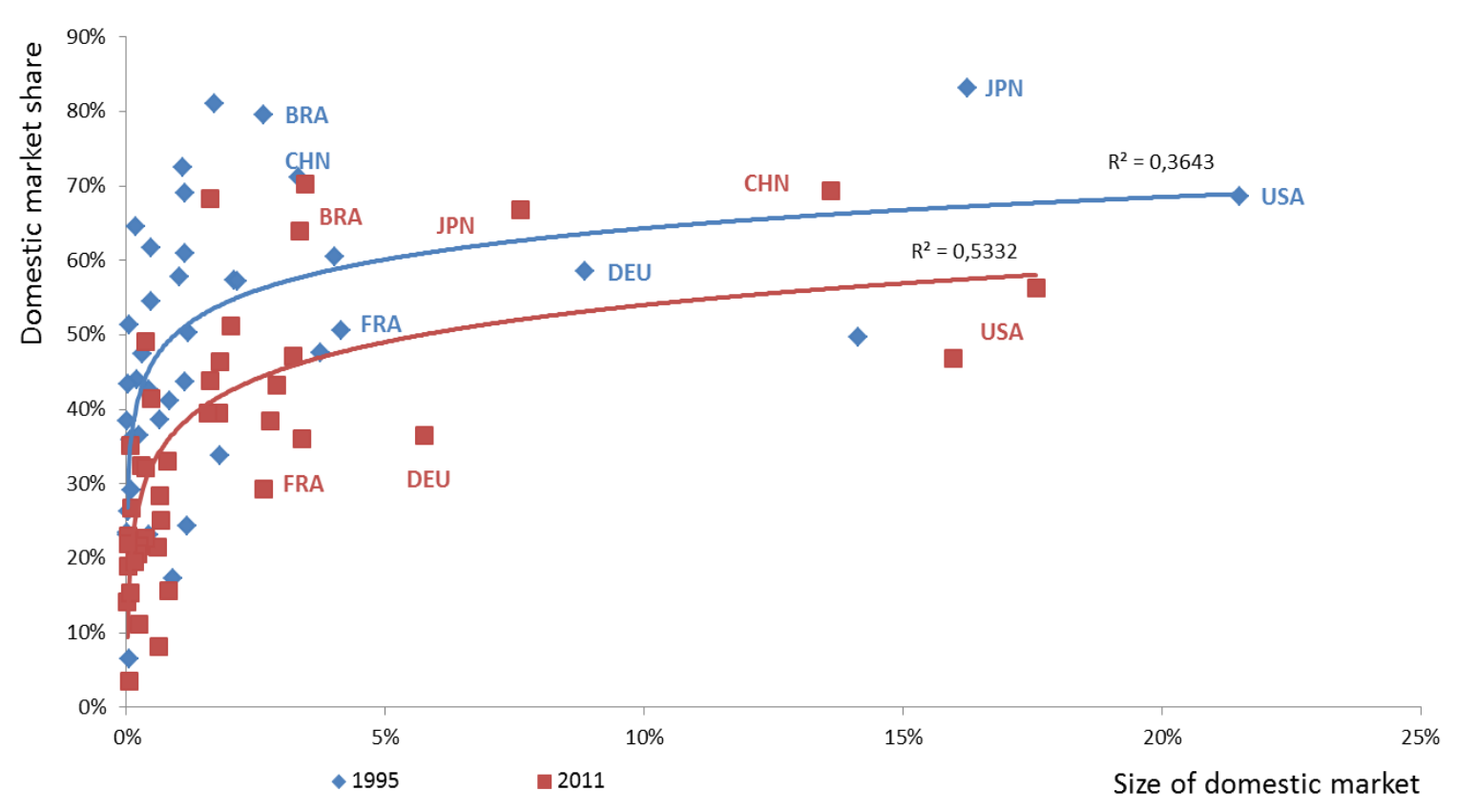

Source: WIOD and authors' calculations.

\section{c. Global performance by sub-periods}

The losses of global market shares recorded by most of European countries over the period 1995-2011 are reversed between 2000 and 2007. During this period, the global performance of all the four Eurozone countries improves, partly due to the introduction of the euro and the intensification of trade, but also due to the exchange rate appreciation that followed. Thereby, Germany $(1.7 \%)$, Spain $(2.7 \%)$, France $(0.2 \%)$ and Italy $(1 \%)$ earn global market shares on annual average during the period. In contrast during the same period all these countries underperform on their own home market; which is more pronounced in Germany $(-2.5 \%)$. Moreover, the relative size of the domestic market compared to the world increase in these Eurozone countries, which explains most of their global performance, except for Germany whose performance is mainly driven by exports.

Between 2007 and 2011, all components of the global market shares shrink for the four Eurozone countries; the only exception is the Spanish performance on its own domestic market. The whole poor performance among these countries is also observed between 1995 and 2000. Likewise, Japan improves its performance during this same last period, especially due to the dynamic of its domestic demand (+2.4\%), after a huge fall from 2000 to 2007 with an average annual decrease of $8 \%$ of its market shares. The United States and United Kingdom win global market shares during the first period between 1995 and 2000; but reverse the dynamic in the following two periods. Finally, China outperforms in all the components of the global market shares indicator during the whole period, except in its domestic market between 2000 and 2007. 
Table 5: Decomposition of the contribution of national and foreign markets to changes in global market shares (on average annual growth rate)

\begin{tabular}{|c|c|c|c|c|c|c|c|c|}
\hline & China & Germany & Spain & France & $\begin{array}{c}\text { United } \\
\text { Kingdom }\end{array}$ & Italy & Japan & $\begin{array}{l}\text { United } \\
\text { States }\end{array}$ \\
\hline \multicolumn{9}{|c|}{$1995-2011$} \\
\hline Globl market share & $9.6 \%$ & $2.3 \%$ & $0.9 \%$ & $2.2 \%$ & $2.8 \%$ & $1.8 \%$ & $4.9 \%$ & $1.8 \%$ \\
\hline Domestic performance & $0.2 \%$ & $2.9 \%$ & & & $3.0 \%$ & & $1.4 \%$ & $1.2 \%$ \\
\hline $\begin{array}{l}\text { Size of the domestic } \\
\text { market }\end{array}$ & $9.2 \%$ & $2.7 \%$ & $1.0 \%$ & $1.3 \%$ & $2.1 \%$ & $1.4 \%$ & $-4.6 \%$ & $1.3 \%$ \\
\hline Export performance & $9.2 \%$ & $1.6 \%$ & $-0.1 \%$ & $3.0 \%$ & $2.9 \%$ & $2.3 \%$ & $4.1 \%$ & $1.8 \%$ \\
\hline \multicolumn{9}{|c|}{ 2007-2011 } \\
\hline Total market share & $10.4 \%$ & $2 \%$ & $6 \%$ & $5.6 \%$ & $.1 \%$ & $5.4 \%$ & $-3 \%$ & $4.6 \%$ \\
\hline Domestic performance & $0.8 \%$ & & & & $.1 \%$ & $.9 \%$ & $0.0 \%$ & p.7\% \\
\hline $\begin{array}{l}\text { Size of the domestic } \\
\text { market }\end{array}$ & $14.3 \%$ & $5 \%$ & $2 \%$ & $2 \%$ & $2 \%$ & $5 \%$ & $.4 \%$ & $5.5 \%$ \\
\hline Export performance & $7.7 \%$ & $.2 \%$ & $1 \%$ & $4.4 \%$ & $6.3 \%$ & $4.6 \%$ & $2.9 \%$ & $1.0 \%$ \\
\hline \multicolumn{9}{|c|}{ 2000-2007 } \\
\hline Total market share & $9.8 \%$ & & & $0.2 \%$ & & $1.0 \%$ & $3.0 \%$ & $4.2 \%$ \\
\hline Domestic performance & $1.0 \%$ & $5 \%$ & & & & $.6 \%$ & $.4 \%$ & $1.6 \%$ \\
\hline $\begin{array}{l}\text { Size of the domestic } \\
\text { market }\end{array}$ & $6.6 \%$ & $.2 \%$ & $4.1 \%$ & & $.4 \%$ & & $3.5 \%$ & $3.7 \%$ \\
\hline Export performance & $12.4 \%$ & & $.5 \%$ & $.7 \%$ & $2.8 \%$ & $.3 \%$ & $5 \%$ & $5.2 \%$ \\
\hline \multicolumn{9}{|c|}{$1995-2000$} \\
\hline Total market share & $8.9 \%$ & $.3 \%$ & $2.9 \%$ & $2.8 \%$ & & $.9 \%$ & $4.0 \%$ & $4.2 \%$ \\
\hline Domestic performance & $0.3 \%$ & $1.2 \%$ & $5.2 \%$ & $.5 \%$ & $1.9 \%$ & $2.0 \%$ & $1.0 \%$ & $1 \%$ \\
\hline $\begin{array}{l}\text { Size of the domestic } \\
\text { market }\end{array}$ & $9.1 \%$ & $5.4 \%$ & $.1 \%$ & & & $0.6 \%$ & $4.5 \%$ & $5.8 \%$ \\
\hline Export performance & $6.0 \%$ & $3.7 \%$ & $0.6 \%$ & $3.6 \%$ & $-0.2 \%$ & $-3.2 \%$ & $-2.4 \%$ & $2.4 \%$ \\
\hline
\end{tabular}

Source: WIOD and authors' calculations.

\section{d. Low correlation between the export and domestic performances}

During the period between 1995 and 2011, the deterioration in the global performances of Japan and Germany compared with those measured by export data alone results from a relatively slower growth in their domestic manufacturing final demand and from a decline in the market shares of national firms on their home markets. Spain relatively strong export performance goes hand in hand with a decline in its domestic market share. France, Italy and the United Kingdom face a simultaneous loss of export and domestic market shares. They differ nonetheless in terms of their resilience in their own home markets, strong in Italy, middling in France and lower in the United Kingdom. 
Thereby, despite a positive relationship, the correlation between both performance indicators is low, about 0.15; while export performance just explains $2 \%$ of domestic performance variance during the period 1995-2011.

Chart 11: Domestic and exports market shares (average annual growth rate, 1995-2011)

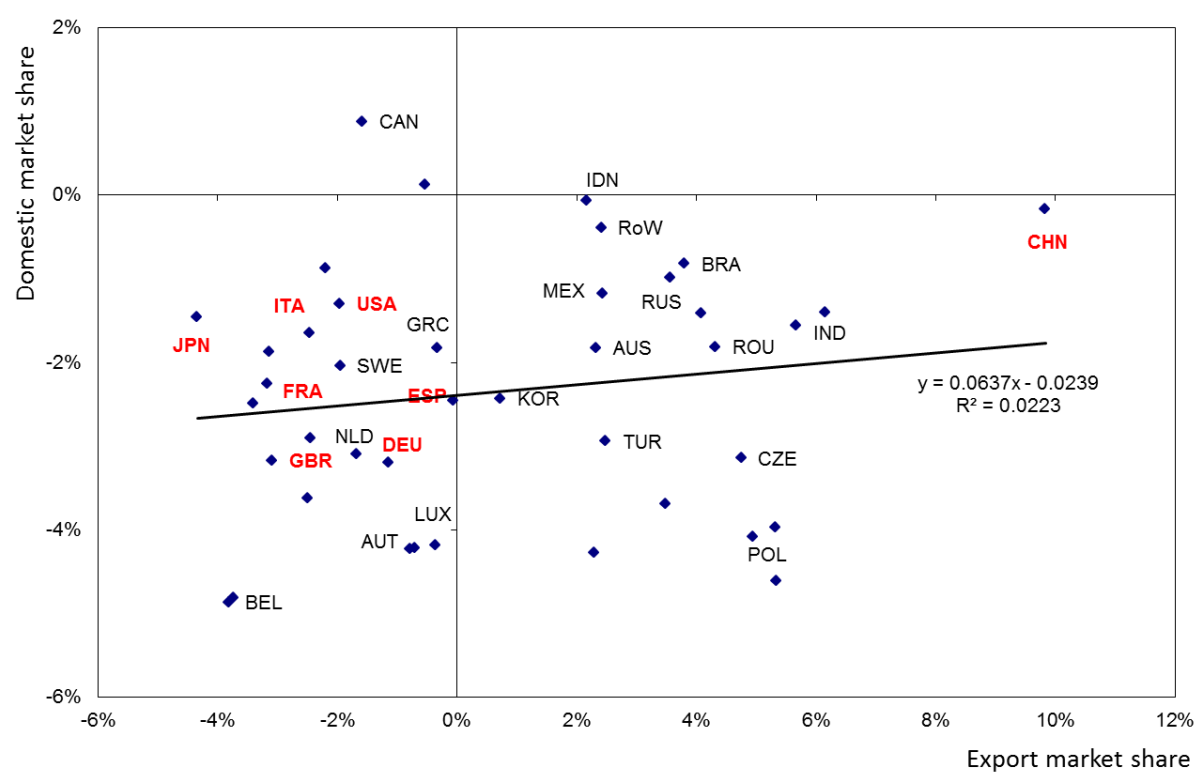

Source: WIOD and authors' calculations.

All large countries, except China, experience a fall on both export and national markets, but not at the same pace (Chart 11). Germany and Spain are interesting cases: both countries maintain their export market shares $(-1.6 \%$ and $-0.1 \%$ on annual average), despite the increasing competition of emerging countries, but they experience strong losses on their domestic market shares (-3\% and $-2.5 \%$, respectively), particularly between 2000 and 2007 . In contrast, for France and Italy, the loss is less pronounced in their home markets (respectively $-2.1 \%$ and $-1.5 \%)$ than for exports $(-3 \%$ and $-2.3 \%)$.

\section{e. Domestic performances and specialization within manufacturing GVCs}

The low correlation between domestic and export performances may reflect greater specialization of domestic production while final demand remains diversified in each country. Chart 12 shows that growing specialization of the production activities serving the manufacturing final demand is accompanied by worse performance of national firms in their home market, and confirms a trend towards specialization in all the rich countries. These results are thus in line with the idea of a specialization in certain specific tasks within the global production chains (Baldwin \& Robert-Nicoud, 2014).

The countries where loss of domestic market shares is greatest, such as the United Kingdom, Germany and Spain, are those in which specialization is also greatest. France, like all the 
other developed countries, loses domestic market share and increases specialization. Conversely, China, which retains its domestic market shares, has diversified its production supply over the period.

Chart 12: Specialization and domestic market shares (average annual growth rate between 1995 and 2011)

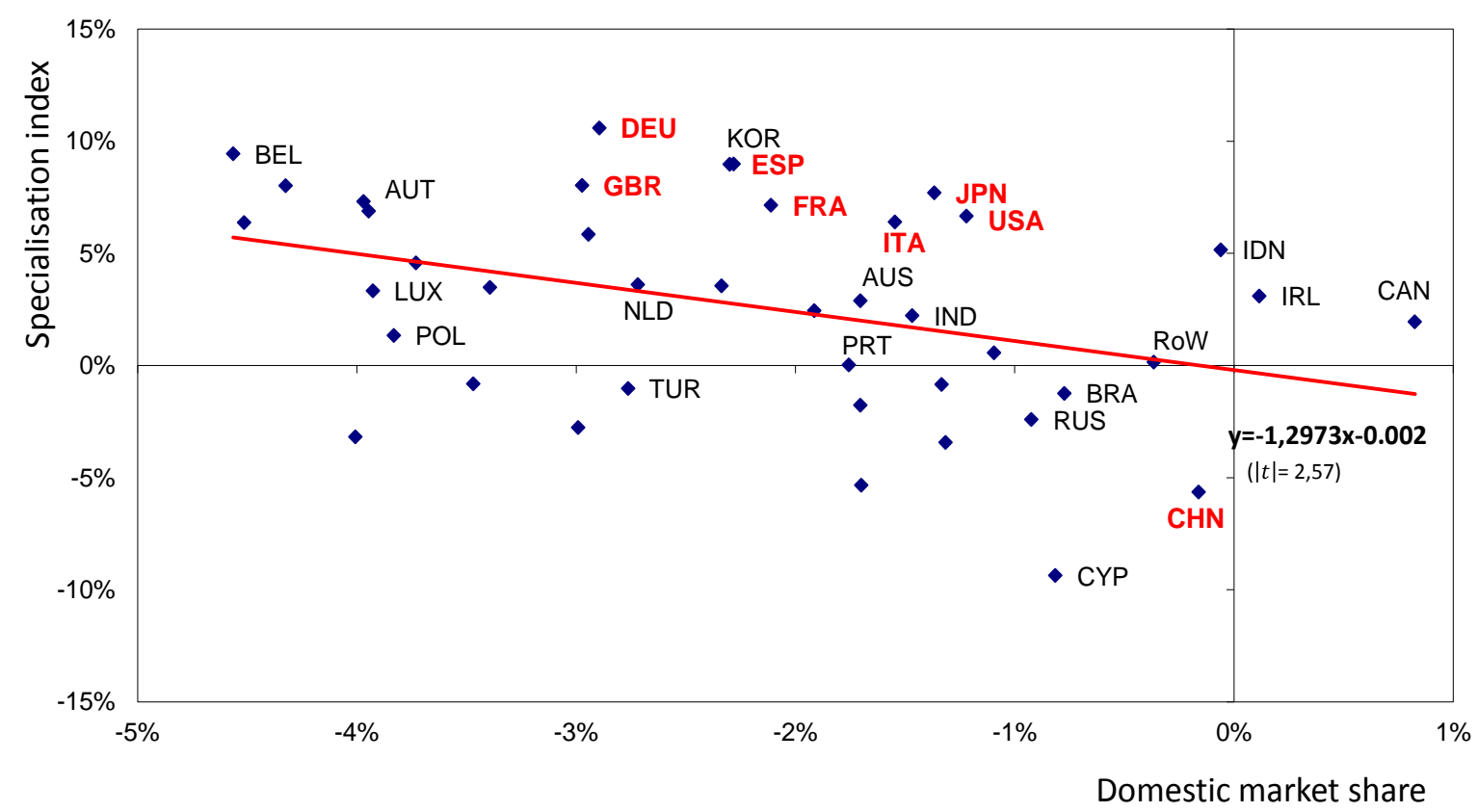

Source: WIOD and authors' calculations.

Note: Specialization index constructed by the weighted standard deviation of Balassa specialization indicator. A rise in the index indicates increased specialization.

The specialization of domestic production systems is measured as the standard deviation of the Balassa indicator weighted by the size of each industry in the world output for the manufacturing final demand. A rise in the indicator shows a higher sectorial intensity in a few number of industries within the manufacturing value chains, i.e. an increase in the sectorial concentration of value added. The traditional Balassa indicator measures countries revealed comparative advantage, computed as the share of an industry in the value added exported on the share of the same industry in the world manufacturing final demand. If the ratio is higher than the unit, the country is relatively specialized in the industry. Appendix 3 presents an analysis on the differences between Balassa indicators computed from traditional gross trade data and from value added within manufacturing value chains data. 


\section{Chart 13: Specialization dynamics with the Balassa weighted standard-deviation index}

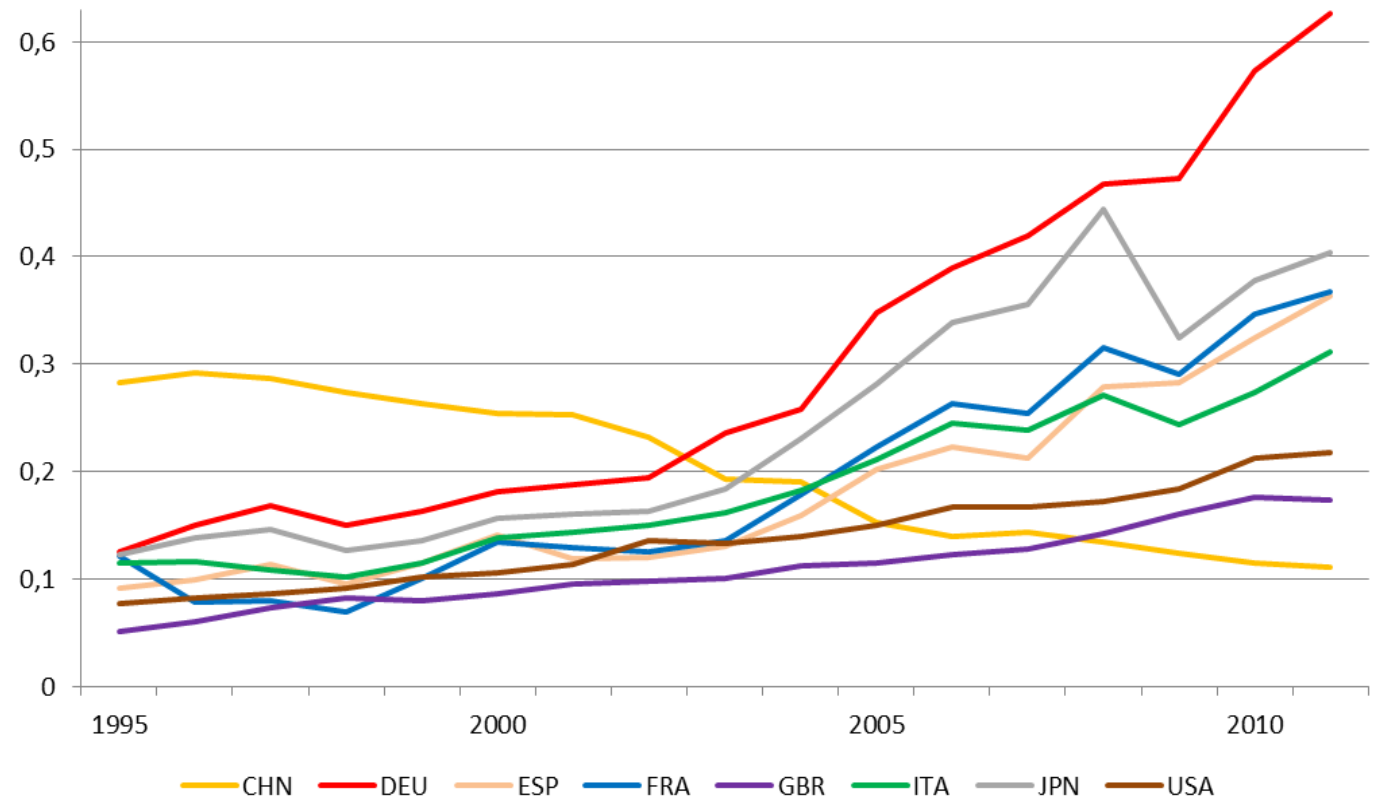

Source: WIOD and authors' calculations..

Chart 13 presents the developments of the weighted indicator during the analyzed period. From 1995 to 2011, and especially from 2003, European countries experience growing specialization of their productive apparatus within the manufacturing value chains, with a growing importance of services sectors (see table A5 in the appendix). During the period, the average annual growth rate of the weighted Balassa indicator reaches around 7\% in France and Italy, $8 \%$ in Spain and $9 \%$ in the United Kingdom. Yet, Germany outperforms with a continuous annual rise of $11 \%$ from 0.13 in 1995 to 0.63 in 2011. In contrast, China is the only country that follows an opposite trend: its specialization index fell from 0.28 to 0.11 during the 17 years.

\section{A second decomposition of export and global performances}

The section proposes a further decomposition of trade performance (exports and global) using a statistical model. For each country the growth rate of exports or exports plus domestic sales is decomposed into a sectorial effect, a geographical effect and an adjusted growth rate or "push" factor that is specific to the trading country (and thus net from geographical and sectorial effects). Indeed, two countries with similar competitiveness may have different overall performance because the demand for the goods they are specialized in (sectorial specialization) or in the markets where they are present (geographical specialization) is growing at different pace. 


\section{a. Methodology}

The empirical strategy is based on Gaulier et al. (2013) and consists of three main steps. First, as in Bricongne et al. (2011), the model computes the export mid-point growth rate, that allows computing growth rate accounting for the intensive and extensive margins of trade. Second, growth rates are decomposed into a sectorial effect, a geographical effect and a country specific effect (as in Cheptea et al. 2005, and Cheptea et al. 2012). Precisely, the midpoint growth rate is regressed by a weighted OLS estimation on three sets of fixed effects: seller (exporter), buyer (importer) and sector/product. The weights are computed by the relative share of flows in total world flows. Finally, the indices from the estimated coefficients are computed, after normalizing the coefficients and standard errors.

More precisely, the mid-point growth rate - for country i selling $x_{i j k t}$ to country j of product $\mathrm{k}$ at time $t$ is defined as follows:

$$
g_{i j k t}=\frac{x_{i j k t}-x_{i j k(t-1)}}{\frac{1}{2}\left(x_{i j k t}+x_{i j k(t-1)}\right)}
$$

The weight of each flow $g_{i j k t}$ is given by the relative share in total trade:

$$
s_{i j k t}=\frac{x_{i j k t}+x_{i j k(t-1)}}{\left(\sum_{j} \sum_{i} \sum_{k} x_{i j k t}+\sum_{j} \sum_{i} \sum_{k} x_{i j k(t-1)}\right)}
$$

This growth rate allows factoring countries entries and exits in new markets and new products, which would otherwise disappear if log-specifications were used. The mid-point growth rate is then regressed on three sets of fixed effects, i.e. seller $(f i)$, buyer $(f \mathrm{j})$ and sector/product $(f k)$ by a weighted OLS estimation:

$$
g_{i j k}^{t}=\alpha+\sum_{i} \emptyset_{i}^{t} f_{i}+\sum_{j} \beta_{j}^{t} f_{j}+\sum_{k} \gamma_{k}^{t} f_{k}+\varepsilon_{i j k t}
$$

To ease the interpretation, the estimated effects are normalized to quantify them as deviations from the average growth rate from the overall sample in the data set, i.e. to world growth. Finally the growth rate of country $i$ exports or sales is the weighted average of individual $g$ for the flows from that country and can be decomposed as follows ${ }^{9}$ :

${ }^{9} G_{i}^{t}$ is a very good approximation of log change of aggregate exports of country i.

$$
G_{i}^{t} \approx \ln \left(\frac{\sum_{j, k} x_{i j k}^{t}}{\sum_{j, k} x_{i j k}^{(t-1)}}\right)
$$




$$
G_{i}^{t}=\sum_{j, k} g_{i j k}^{t} \cdot s_{i j k}^{t}=\widetilde{\emptyset_{l}^{t}}+\sum_{c} s_{i j}^{t} \tilde{\beta}_{j}^{t}+\sum_{k} s_{i k}^{t} \tilde{\gamma}_{k}^{t}
$$

The first term in the right hand side of the equation is the "push effect" or adjusted growth rate; the second and third terms are respectively the geographical and sectorial effects.

\section{b. Export and global shift-share decompositions}

Table 6 shows the exports and global (exports and domestic) growth rates for the eight countries in our sample and for the world, decomposed in a country performance effect, a geographical effect, and a sectorial effect. The first effect gives the role of countries specific factors in their external or domestic performance. The geographical effect determines if countries performance is driven by the markets they serve, including their home market for the global performance; and the sectorial effect indicates if sales growth rate is driven by countries' sectorial specialization. In addition, in order to qualify the relative adjusted country effect, the last column shows the difference between national and world average performances net from specialization effects. In the table, growth rate in current US dollars is computed from bilateral trade data on sectorial level from the whole period between 1995 and 20011. Trade flows are measured in domestic value added exchanged within the manufacturing global value chains, i.e. value added produced to address manufacturing final demand. Export columns include only international trade flows; whereas global columns include international trade flows and also trade flows within the domestic markets. In the former case, one proceeds to a decomposition of world trade, while in the latter to a decomposition of world gross production, i.e. of world total value added for manufacturing value chains.

The shift share decomposition performed during the whole period and in current prices confirms the overall trend reported above in the study. Exports and global growth rates are always positive for all countries during the analyzed period, except for Japan when its domestic market is taken into account, such that the deterioration on export and global market shares recorded before are always relative to the world average. The shift share decomposition confirms the finding of the decomposition performed in the previous section of a convergence of European countries' global performances if their home markets are taken into account. German (2.3\%), French (2.3\%), British (1.7\%) and Italian (2.7\%) global performances are thus closer than their export-only performances (which are respectively of $4.7 \%, 3.2 \%, 3.3 \%$ and $3.9 \%$ ). For the relative adjusted country's performance effect, as expected China performs better than world average both for export and global indicators (9.8\% and $7.3 \%$ respectively). European countries' relative adjusted performances are worse than the world average for exports, except in Spain that outperforms $(0.5 \%)$. For global relative adjusted performance, Spain performs closer to the world average $(-0.3 \%)$; whereas all other Europeans countries lose market shares. The loss is nonetheless less pronounced than with export-only data for the European countries, except for Spain. For the United States and 
Japan, their relative adjusted effects are the lowest among the rich countries in the sample, but the trend is softened if their domestic markets are included in the analysis.

Table 6: Export and Global Shift-shares decompositions between 1995 and 2011

\begin{tabular}{|c|c|c|c|c|c|c|c|c|c|c|}
\hline & \multicolumn{5}{|c|}{ Export } & \multicolumn{5}{|c|}{ Global (Export + Domestic) } \\
\hline & Growth rate & Geography & Sector & $\begin{array}{c}\text { Adjusted country } \\
\text { effect* }\end{array}$ & $\begin{array}{c}\text { Relative adjusted } \\
\text { country effect }\end{array}$ & Growth rate & Geography & Sector & $\begin{array}{l}\text { Adjusted country } \\
\text { effect* }\end{array}$ & $\begin{array}{c}\text { Relative adjusted } \\
\text { country effect }\end{array}$ \\
\hline \multicolumn{11}{|c|}{ Current prices (US\$) } \\
\hline China & $14.6 \%$ & $-0.7 \%$ & $-0.6 \%$ & $16.0 \%$ & $9.8 \%$ & $13.4 \%$ & $1.9 \%$ & $-0.4 \%$ & $11.9 \%$ & $7.3 \%$ \\
\hline Germany & $4.7 \%$ & $0.0 \%$ & $0.0 \%$ & $4.7 \%$ & $-1.5 \%$ & $2.3 \%$ & $-1.0 \%$ & $0.1 \%$ & $3.2 \%$ & $-1.4 \%$ \\
\hline Spain & $6.1 \%$ & $-0.4 \%$ & $-0.2 \%$ & $6.7 \%$ & $0.5 \%$ & $3.7 \%$ & $-0.4 \%$ & $-0.2 \%$ & $4.3 \%$ & $-0.3 \%$ \\
\hline France & $3.2 \%$ & $-0.3 \%$ & $0.0 \%$ & $3.4 \%$ & $-2.8 \%$ & $2.3 \%$ & $-0.4 \%$ & $0.0 \%$ & $2.7 \%$ & $-1.9 \%$ \\
\hline United Kingdom & $3.3 \%$ & $-0.2 \%$ & $0.2 \%$ & $3.4 \%$ & $-2.8 \%$ & $1.7 \%$ & $-0.5 \%$ & $0.1 \%$ & $2.2 \%$ & $-2.4 \%$ \\
\hline Italy & $3.9 \%$ & $0.0 \%$ & $-0.3 \%$ & $4.2 \%$ & $-2.0 \%$ & $2.7 \%$ & $-0.3 \%$ & $-0.2 \%$ & $3.3 \%$ & $-1.3 \%$ \\
\hline Japan & $2.2 \%$ & $0.7 \%$ & $-0.1 \%$ & $1.6 \%$ & $-4.6 \%$ & $-0.6 \%$ & $-1.9 \%$ & $0.0 \%$ & $1.4 \%$ & $-3.2 \%$ \\
\hline United States & $4.5 \%$ & $0.6 \%$ & $0.1 \%$ & $3.8 \%$ & $-2.4 \%$ & $2.8 \%$ & $-0.4 \%$ & $0.1 \%$ & $3.0 \%$ & $-1.6 \%$ \\
\hline \multirow[t]{2}{*}{ World } & $6.2 \%$ & $0.0 \%$ & $0.0 \%$ & $6.2 \%$ & $0.0 \%$ & $4.6 \%$ & $0.0 \%$ & $0.0 \%$ & $4.6 \%$ & $0.0 \%$ \\
\hline & $(T=G+S+A G)$ & (G) & (S) & $(A G)$ & (AG-World) & & & & & \\
\hline
\end{tabular}

Generally, geographical and sectorial factors are marginal compared to countries' own adjusted performance factor. This is mainly explained by the geographical coverage of data and the level of industrial disaggregation. However, taking into account the domestic markets change the diagnosis based on the decomposition and presents interesting results. In current prices, the geographical factor is negative for Chinese export performance $(-0.7 \%)$ since Chinese exports do not benefit from the dynamic of its own home market; whereas this same geographical factor become highly positive (1.9\%) if the analysis is performed on the global manufacturing value added, which takes into account the Chinese market. In contrast, American and Japanese geographical factor are positives for exports (respectively $0.7 \%$ and $0.6 \%$ ) and negative for the global performance (-1.9\% and $-0.4 \%)$ since developments in their own home markets are downward relatively to the world average between 1995 and 20011. Germany follows the same trend and its geographical effect diminishes from a neutral $0 \%$ to a negative $-1 \%$ if the German market is added to the analysis. Among the other European countries; the geographical specialization of the United Kingdom and Italy are better without their home markets. It is not the case for Spain and France, which do not change their geographical factor if their home markets are taken into account. 
Table 7: Shift-share decompositions in previous years' price between 1999 and 2007

\begin{tabular}{|c|c|c|c|c|c|c|c|c|c|c|}
\hline & \multicolumn{5}{|c|}{ Export } & \multicolumn{5}{|c|}{ Global (Export + Domestic) } \\
\hline & Growth rate & Geography & Sector & $\begin{array}{l}\text { Adjusted country } \\
\text { effect* }\end{array}$ & $\begin{array}{c}\text { Relative adjusted } \\
\text { country effect }\end{array}$ & Growth rate & Geography & Sector & $\begin{array}{c}\text { Adjusted } \\
\text { country effect* }\end{array}$ & $\begin{array}{c}\text { Relative adjusted } \\
\text { country effect }\end{array}$ \\
\hline \multicolumn{11}{|c|}{ Current prices (US\$) } \\
\hline China & $20.6 \%$ & $-1.0 \%$ & $-0.6 \%$ & $22.3 \%$ & $13.2 \%$ & $15.4 \%$ & $0.4 \%$ & $-0.3 \%$ & $15.3 \%$ & $9.0 \%$ \\
\hline Germany & $9.3 \%$ & $0.4 \%$ & $0.0 \%$ & $9.0 \%$ & $0.0 \%$ & $6.1 \%$ & $-0.5 \%$ & $0.1 \%$ & $6.5 \%$ & $0.2 \%$ \\
\hline Spain & $9.1 \%$ & $-0.2 \%$ & $-0.2 \%$ & $9.6 \%$ & $0.5 \%$ & $7.0 \%$ & $0.9 \%$ & $-0.3 \%$ & $6.4 \%$ & $0.2 \%$ \\
\hline France & $5.9 \%$ & $0.1 \%$ & $0.0 \%$ & $5.8 \%$ & $-3.2 \%$ & $4.7 \%$ & $0.1 \%$ & $0.0 \%$ & $4.5 \%$ & $-1.7 \%$ \\
\hline United Kingdom & $5.6 \%$ & $0.1 \%$ & $0.1 \%$ & $5.3 \%$ & $-3.7 \%$ & $3.6 \%$ & $-0.3 \%$ & $0.0 \%$ & $3.9 \%$ & $-2.3 \%$ \\
\hline Italy & $7.5 \%$ & $0.3 \%$ & $-0.4 \%$ & $7.6 \%$ & $-1.5 \%$ & $5.6 \%$ & $0.1 \%$ & $-0.3 \%$ & $5.8 \%$ & $-0.5 \%$ \\
\hline Japan & $4.3 \%$ & $0.5 \%$ & $-0.2 \%$ & $4.0 \%$ & $-5.0 \%$ & $-0.2 \%$ & $-2.8 \%$ & $-0.1 \%$ & $2.6 \%$ & $-3.6 \%$ \\
\hline United States & $5.4 \%$ & $0.8 \%$ & $0.0 \%$ & $4.6 \%$ & $-4.4 \%$ & $2.3 \%$ & $-1.0 \%$ & $0.1 \%$ & $3.2 \%$ & $-3.0 \%$ \\
\hline World & $9.0 \%$ & $0.0 \%$ & $0.0 \%$ & $9.0 \%$ & $0.0 \%$ & $6.2 \%$ & $0.0 \%$ & $0.0 \%$ & $6.2 \%$ & $0.0 \%$ \\
\hline \multicolumn{11}{|c|}{ Previous years' prices (volume growth rate) } \\
\hline China & $17.3 \%$ & $-0.7 \%$ & $-0.4 \%$ & $18.4 \%$ & $12.5 \%$ & $11.9 \%$ & $0.7 \%$ & $-0.2 \%$ & $11.4 \%$ & $8.1 \%$ \\
\hline Germany & $6.2 \%$ & $0.1 \%$ & $0.3 \%$ & $5.8 \%$ & $0.0 \%$ & $2.6 \%$ & $-0.9 \%$ & $0.4 \%$ & $3.2 \%$ & $-0.1 \%$ \\
\hline Spain & $3.7 \%$ & $-0.4 \%$ & $-0.2 \%$ & $4.3 \%$ & $-1.5 \%$ & $1.3 \%$ & $0.5 \%$ & $-0.4 \%$ & $1.2 \%$ & $-2.1 \%$ \\
\hline France & $3.4 \%$ & $-0.2 \%$ & $0.1 \%$ & $3.6 \%$ & $-2.3 \%$ & $2.1 \%$ & $-0.1 \%$ & $0.0 \%$ & $2.2 \%$ & $-1.2 \%$ \\
\hline United Kingdom & $1.6 \%$ & $-0.1 \%$ & $0.2 \%$ & $1.4 \%$ & $-4.5 \%$ & $0.1 \%$ & $0.0 \%$ & $0.0 \%$ & $0.1 \%$ & $-3.3 \%$ \\
\hline Italy & $2.7 \%$ & $0.1 \%$ & $-0.4 \%$ & $3.1 \%$ & $-2.8 \%$ & $0.6 \%$ & $-0.5 \%$ & $-0.3 \%$ & $1.4 \%$ & $-1.9 \%$ \\
\hline Japan & $6.8 \%$ & $0.6 \%$ & $0.4 \%$ & $5.9 \%$ & $0.0 \%$ & $2.8 \%$ & $-1.8 \%$ & $0.4 \%$ & $4.2 \%$ & $0.9 \%$ \\
\hline United States & $4.7 \%$ & $0.9 \%$ & $0.3 \%$ & $3.6 \%$ & $-2.3 \%$ & $1.7 \%$ & $-0.3 \%$ & $0.3 \%$ & $1.8 \%$ & $-1.6 \%$ \\
\hline \multirow[t]{2}{*}{ World } & $5.8 \%$ & $0.0 \%$ & $0.0 \%$ & $5.8 \%$ & $0.0 \%$ & $3.3 \%$ & $0.0 \%$ & $0.0 \%$ & $3.3 \%$ & $0.0 \%$ \\
\hline & \multicolumn{2}{|c|}{$(T=G+S+A G)(G)$} & (S) & $(A G)$ & (AG-World) & & & & & \\
\hline
\end{tabular}

Furthermore, we perform the same exercise on sales growth in volume. Data on previous years' prices is produced by WIOD for the period 1996-2009 only. ${ }^{10}$ We thus opted to perform the analysis from 1999 to 2007; for that the onset of the decomposition coincides with the implementation of the euro - such that differences in Euro countries' adjusted effects are not imputed to differences in exchange rate dynamics - and to complete it before the start of the great financial crisis.

The shift share decomposition performed with data on volume traded, which adjusts for price fluctuations, also presents interesting results and shows that the dynamics of export and domestic prices impact the measures of performance. Japan improves its export and global measures in real terms and the country surpasses Germany as the second best performer in the sample between 1999 and 2007. We attribute this improvement to the depreciation of the yen and to the Japanese deflation during the period that shrunken its nominal performance. In contrast, German global growth rate is downward in volume compared to data on current prices; mainly due to the depressive dynamic on its own home market, which seems to be more pronounced in real than in nominal terms. Hence, the geographical factor in the

\footnotetext{
${ }^{10}$ For more details, see Los et al (2014).
} 
composition of the variation of German global market shares drops to $-0.9 \%$ in real terms from $-0.5 \%$ in nominal. For France, both export and global relative adjusted performances (adjusted country effect relative to the world performance) improve in real terms by respectively 1 and 0.5 points; whereas Spanish relative adjusted performances in real terms strongly deteriorate during the eight years; and both growth rates drop by 2 points. The improvement in French overall performance goes in hand with the previous results and the moderation in the country's inflation relative to the rest of the world explains that its real indicator is better than the nominal. In addition, a relative lower price increase in France than in Spain explains these divergences between both countries. Moreover, the United States and United Kingdom follow opposite trends. The former country improves its performance in real terms compared to nominal while the latter worsens it; mainly due to the divergences in their exchange rates dynamics.

\section{Conclusions}

We identified two constraints of conventional analysis of countries performance from traditional export market share indicators: they take into account neither the import content of exports nor the performance of national firms on their home market. Indeed, international production chains become increasingly important along with the use of foreign inputs in the production process; such that traditional export data can be biased; whereas the home market is generally the leading market for national firms, and is thus a prominent parameter for analyzing the competitiveness and dynamism of domestic firms. Furthermore, services sectors become indispensable to measure the participation of rich countries on manufacturing value chains and traditional data do not necessarily cover all activities related to the manufacturing production.

The "global" market share indicator developed in this paper proposes an approach to overcome these limitations: i/ it identifies the import content in output and takes into account the sole domestic value added in production; ii/ it incorporates the performance of domestic firms in their domestic market; and iii/ it is constructed from data that consider all activities used in the production to address the manufacturing final demand, including services.

The paper shows that despite the rise of the import content of exports, export market shares computed from value added trade do not substantially affect the diagnosis issue from gross traditional data. Nonetheless, taking services sectors into account reduces the gap in the dynamics of European countries, especially due to the increasing importance of the value added from services within the manufacturing value chains. Furthermore, the convergence in the dynamics of market shares of most European countries is even more pronounced when the performance of national firms in their domestic market is taken into account. Thus our results suggest that there is no polarization of the manufacturing production within the European Union. We then proceed to a decompose our global indicator into its components and show a de-correlation between the export and domestic performances partly reflecting greater 
specialization of domestic production while final demand remains diversified. We finally proceed to a second decomposition of market shares growth rate; which quantifies countries specific performances and captures the extent to which these reflect geographical specialization, sectorial specialization, or other country specific determinants. The overall trend reported by the first decomposition is confirmed by this new method: countries' performances (mainly European) converge if their domestic markets are taken into account along with their export performances. 


\section{References}

Amador (J.), Cappariello (R.) \& Stehrer (R.) (2015). «Global value chains: a view from the euro area », European Central Bank Working paper series, No 1761, March 2015.

Baldwin (R.) (2012), « Global supply chains : why they emerged, why they matter, and where they are going », Centre for economic policy research, Discussion paper series, $n^{\circ} 9103$

Baldwin (R.) \& Robert-Nicoud (F.) (2014) «Trade-in-goods and trade-in-tasks: An integrating framework» Journal of International Economics, Elsevier, vol. 92(1), pages 51-62.

Bems (R.), Johnson (R. C.) \& Yi (K.-M.) (2011) «Vertical linkages and the collapse of global trade », American Economic Review, 101(3), 308-12.

Benkovskis (K.) \& Wörtz (J.) (2015) " "Made in China": How does it affect our understanding of global market shares? », European Central Bank Working paper Seires, 1787

Bernard (A.) \& Fort (T.) (2013) «Factoryless Goods Producers in the US », NBER Working Paper, $\mathrm{n}^{\circ} 19396$.

Bernard (A.), Smeets (V.) \& Warzynski (F.) (2014) «Rethinking Deindustrialization », Economics Working Papers $\mathrm{n}^{\circ} 14$, School of Economics and Management, University of Aarhus.

Bricongne (J.-C.), Fontagne (L.), Gaulier (G.), Taglioni (D.) \& Vicard (V.) (2012), « Firms and the Global Crisis: French exports in the turmoil », Journal of International Economics 87, 1 134-146.

Cezar (R.) (2016a) «France's trade integration measured in value added », Quarterly Selection of Articles Banque de France Bulletin, issue 43, pages 47-58, Autumn.

Cezar (R.) (2016b) «France's pharmaceutical industry in global value chains», Quarterly Selection of Articles Banque de France Bulletin, issue 44, pages 52-63, Winter.

Cezar (R.), Duguet (A.), Gaulier (G.) \& Vicard (V.) (2016) «Competition for global value added: domestic and export market shares », Quarterly Selection of Articles Banque de France Bulletin, issue 41, pages 5-15, spring.

Chen (X.), Cheng (L.), Fung (K.C.), Lau (L.), Sung (Y.), Yang (C.), Zhu (K.), Pei (J) \& Duan (Y.) (2012) «Domestic Value Added and Employment Generated by Chinese Exports: A Quantitative Estimation », China Economic Review, 23:850-864.

Cheptea (A.), Fontagne (L.) \& Zignago (S.) (2012), « European Export Performance », Banque de France Working Paper 393.

Cheptea (A.), Gaulier (G.) \& Zignago (S.) (2005) « World Trade Competitiveness: a Disaggregated View by Shift-Share Analysis », CEPII Working Paper 23.

Daudin (G.), Monperrus-Veroni (P.), Rifflart (C.) \& Schweisguth (D.) (2006) « Le commerce extérieur en valeur ajoutée », Revue de l'OFCE, Presses de Sciences-Po, vol. 98(3), 129-165.

Demmou (L.) (2010) « Le recul de l'emploi industriel en France entre 1980 et 2007, Ampleur et principaux déterminants : un état des lieux », Economie et Statistiques, n438-440. 
Gaulier (G.), Santoni (G.), Taglioni (D.) \& Zignago (S.) (2013) «In the Wake of the Global Crisis Evidence from a New Quarterly Database of Export Competitiveness », The World Bank Policy Research Working Paper 6733.

Johnson (R.) \& Noguera (G.) (2012) « Accounting for intermediates: production sharing and trade in value added », Journal of International Economics, $\mathrm{n}^{\circ}$ 86(2), p.224-36.

Kee (H.L.) \& Tang (H.) (2016) «Domestic Value Added in Exports : Theory and firm evidence from China », American Economic Review, 106(6) : 1402-1436

Koopman (R.), Wang (Z.) \& Shang-Jin (W.) (2012) « Estimating domestic content in exports when processing trade is pervasive » Journal of Development Economics, Elsevier, vol. 99(1), pages $178-189$.

Koopman (R.), Wang (Z.) \& Wei (S.-J.) (2014) « Tracing Value-Added and Double Counting in Gross Exports », American Economic Review, 104(2), 459-94.

Kraemer (K.), Linden (G.) \& Dedrick (J.) (2011) « Capturing Value in Global Networks: Apple's iPad and iPhone » research supported by the Alfred P. Sloan Foundation and the U.S. National Science Foundation (CISE/IIS)

Le Saux (L.) \& Vicard (V.) (2014) « Les coûts du travail des services domestiques incorporés aux exportations pèsent-ils sur la compétitivité-coût ? », Bulletin de la Banque de France, $\mathrm{n}^{\circ}$ 197, p.55-65

Lemoine (F.) \& Ünal (D.) (2012) « The rebalancing of China's foreign trade », La Lettre du CEPII, $\mathrm{n}^{\circ} 320$

Lemoine (F.) \& Ünal (D.) (2015) « Mutations du commerce extérieur chinois », La Lettre du CEPII, $\mathrm{n}^{\circ} 352$

Los (B.), Gouma (R.), Timmer (M.) \& IJtsma (P.) (2014) « Note on the Construction of WIOTs in Previous Year's Prices » (December -release).

Hans-Werner (S.) (2005) «Basar-Ökonomie Deutschland - Exportweltmeister oder Schusslicht? », Ifo Schnelldienst, Ifo Institute - Leibniz Institute for Economic Research at the University of Munich, vol. 58(06)

Stehrer (R.) (2013) « Accounting Relations in Bilateral Value Added Trade », Wiiw Working Paper 101.

Timmer (M.) (ed) (2012), « The World Input-Output Database (WIOD): Contents, Sources and Methods », WIOD Working Paper, $\mathrm{n}^{\circ} 10$.

Timmer (M.), Dietzenbacher (E.), Los (B.), Stehrer (S.) \& de Vries (J.) (2015) « An Illustrated User Guide to the World Input-Output Database: the Case of Global Automotive Production » Review of International Economics, 23(3), 575-605.

Timmer (M.P.), Erumban (A.A.), Los (B.), Stehrer (R.) and de Vries (G.J.) (2014) « Slicing up global value chains », Journal of Economic Perspectives, Vol 28, N. 2, Pages 99-118.

Timmer (M.), Los (B.), Stehrer (R.) \& de Vries (G.) (2013), «Fragmentation, incomes and jobs: an analysis of European competitiveness », Economic Policy, October p. 613-661. 


\section{Appendix 1: tables}

Table A1: Gross export market shares (annual average growth rate)

\begin{tabular}{|c|c|c|c|c|c|c|c|c|}
\hline & China & Germany & Spain & France & $\begin{array}{c}\text { United } \\
\text { Kingdom }\end{array}$ & Italy & Japan & $\begin{array}{l}\text { United } \\
\text { States }\end{array}$ \\
\hline \multicolumn{9}{|c|}{ Total exports } \\
\hline 1995-2011 & $8.5 \%$ & $-1.2 \%$ & $0.3 \%$ & $-3.1 \%$ & $-2.3 \%$ & $-2.5 \%$ & $-3.7 \%$ & $-2.0 \%$ \\
\hline $1995-2000$ & $5.8 \%$ & $-3.4 \%$ & $0.3 \%$ & $-3.9 \%$ & $-0.1 \%$ & $-3.9 \%$ & $-3.4 \%$ & $0.5 \%$ \\
\hline $2000-2007$ & $11.8 \%$ & $1.6 \%$ & $1.0 \%$ & $-2.7 \%$ & $-2.2 \%$ & $-0.5 \%$ & $-5.2 \%$ & $-4.7 \%$ \\
\hline 2007-2011 & $6.5 \%$ & $-3.4 \%$ & $-1.0 \%$ & $-2.8 \%$ & $-4.9 \%$ & $-3.9 \%$ & $-1.2 \%$ & $-0.3 \%$ \\
\hline \multicolumn{9}{|c|}{ Manufacturing exports } \\
\hline $1995-2011$ & $9.6 \%$ & $-0.8 \%$ & $0.1 \%$ & $-2.4 \%$ & $-3.7 \%$ & $-2.0 \%$ & $-3.3 \%$ & $-2.0 \%$ \\
\hline $1995-2000$ & $5.5 \%$ & $-3.1 \%$ & $-0.1 \%$ & $-2.6 \%$ & $-1.7 \%$ & $-3.5 \%$ & $-3.3 \%$ & $1.7 \%$ \\
\hline $2000-2007$ & $14.1 \%$ & $2.1 \%$ & $1.1 \%$ & $-2.0 \%$ & $-4.7 \%$ & $0.0 \%$ & $-4.8 \%$ & $-5.3 \%$ \\
\hline 2007-2011 & $7.2 \%$ & $-2.7 \%$ & $-1.2 \%$ & $-2.8 \%$ & $-4.3 \%$ & $-3.3 \%$ & $-0.7 \%$ & $-0.5 \%$ \\
\hline
\end{tabular}

Table A2: Value added export market shares (annual average growth rate)

\begin{tabular}{|c|c|c|c|c|c|c|c|c|}
\hline & China & Germany & Spain & France & $\begin{array}{c}\text { United } \\
\text { Kingdom }\end{array}$ & Italy & Japan & $\begin{array}{l}\text { United } \\
\text { States }\end{array}$ \\
\hline \multicolumn{9}{|c|}{ Total exports } \\
\hline 1995-2011 & $8.4 \%$ & $-1.6 \%$ & $0.0 \%$ & $-3.4 \%$ & $-2.0 \%$ & $-2.7 \%$ & $-3.9 \%$ & $-1.8 \%$ \\
\hline $1995-2000$ & $6.3 \%$ & $-3.8 \%$ & $-0.7 \%$ & $-4.3 \%$ & $0.8 \%$ & $-3.7 \%$ & $-2.9 \%$ & $0.4 \%$ \\
\hline 2000-2007 & $10.8 \%$ & $1.3 \%$ & $1.2 \%$ & $-2.4 \%$ & $-1.3 \%$ & $-0.7 \%$ & $-5.6 \%$ & $-4.0 \%$ \\
\hline 2007-2011 & $6.8 \%$ & $-4.0 \%$ & $-1.4 \%$ & $-3.9 \%$ & $-6.3 \%$ & $-4.9 \%$ & $-2.1 \%$ & $-0.7 \%$ \\
\hline \multicolumn{9}{|c|}{ Manufacturing exports } \\
\hline 1995-2011 & $9.7 \%$ & $-1.1 \%$ & $-0.2 \%$ & $-3.4 \%$ & $-3.7 \%$ & $-2.3 \%$ & $-3.5 \%$ & $-1.1 \%$ \\
\hline $1995-2000$ & $7.7 \%$ & $-4.1 \%$ & $-0.3 \%$ & $-1.8 \%$ & $-1.6 \%$ & $-3.4 \%$ & $-2.7 \%$ & $1.7 \%$ \\
\hline 2000-2007 & $12.3 \%$ & $2.4 \%$ & $1.2 \%$ & $-2.5 \%$ & $-4.1 \%$ & $0.0 \%$ & $-5.0 \%$ & $-4.3 \%$ \\
\hline $2007-2011$ & $7.8 \%$ & $-3.4 \%$ & $-2.7 \%$ & $-6.8 \%$ & $-5.6 \%$ & $-4.7 \%$ & $-2.1 \%$ & $1.2 \%$ \\
\hline
\end{tabular}

Source: WIOD and authors' calculations.. 


\section{Table A3: Industries in WIOD database}

\begin{tabular}{|c|c|}
\hline ISIC Rev 3.1 & Industries \\
\hline AtB & Agriculture, Hunting, Forestry and Fishing \\
\hline C & Mining and Quarrying \\
\hline $15 t 16$ & Food, Beverages and Tobacco \\
\hline $17 \mathrm{t} 18$ & Textiles and Textile Products \\
\hline 19 & Leather, Leather and Footwear \\
\hline 20 & Wood and Products of Wood and Cork \\
\hline $21 \mathrm{t} 22$ & Pulp, Paper, Paper, Printing and Publishing \\
\hline 23 & Coke, Refined Petroleum and Nuclear Fuel \\
\hline 24 & Chemicals and Chemical Products \\
\hline 25 & Rubber and Plastics \\
\hline 26 & Other Non-Metallic Mineral \\
\hline $27 \mathrm{t} 28$ & Basic Metals and Fabricated Metal \\
\hline 29 & Machinery, Nec \\
\hline $30 t 33$ & Electrical and Optical Equipment \\
\hline $34 \mathrm{t} 35$ & Transport Equipment \\
\hline $36 \mathrm{t} 37$ & Manufacturing, Nec; Recycling \\
\hline $\mathrm{E}$ & Electricity, Gas and Water Supply \\
\hline $\mathrm{F}$ & Construction \\
\hline 50 & Sale, Maintenance and Repair of Motor Vehicles and Motorcycles; Retail Sale of Fuel \\
\hline 51 & Wholesale Trade and Commission Trade, Except of Motor Vehicles and Motorcycles \\
\hline 52 & Retail Trade, Except of Motor Vehicles and Motorcycles; Repair of Household Goods \\
\hline $\mathrm{H}$ & Hotels and Restaurants \\
\hline 60 & Inland Transport \\
\hline 61 & Water Transport \\
\hline 62 & Air Transport \\
\hline 63 & Other Supporting and Auxiliary Transport Activities; Activities of Travel Agencies \\
\hline 64 & Post and Telecommunications \\
\hline J & Financial Intermediation \\
\hline 70 & Real Estate Activities \\
\hline $71 \mathrm{t} 74$ & Renting of M\&Eq and Other Business Activities \\
\hline L & Public Admin and Defence; Compulsory Social Security \\
\hline M & Education \\
\hline $\mathrm{N}$ & Health and Social Work \\
\hline $\mathrm{O}$ & Other Community, Social and Personal Services \\
\hline$P$ & Private Households with Employed Persons \\
\hline
\end{tabular}




\section{Table A4: Countries in WIOD database}

\begin{tabular}{llll}
\hline AUS & Australia & SVK & Slovak Republic \\
AUT & Austria & SVN & Slovenia \\
BEL & Belgium & ESP & Spain \\
CAN & Canada & SWE & Sweden \\
CZE & Czech Republic & TUR & Turkey \\
DNK & Denmark & GBR & United Kingdom \\
EST & Estonia & USA & United States \\
FIN & Finland & BRA & Brazil \\
FRA & France & BGR & Bulgaria \\
DEU & Germany & CHN & China \\
GRC & Greece & CYP & Cyprus \\
HUN & Hungary & IND & India \\
IRL & Ireland & IDN & Indonesia \\
ITA & Italy & LVA & Latvia \\
JPN & Japan & LTU & Lithuania \\
KOR & Korea & MLT & Malta \\
LUX & Luxembourg & ROU & Romania \\
MEX & Mexico & RUS & Russia \\
NLD & Netherlands & TWN & Chinese Taipei \\
POL & Poland & ROW & Rest of the World \\
PRT & Portugal & & \\
\hline
\end{tabular}




\section{Appendix 2: Exports market shares within the manufacturing global value chains}

Manufacturing export market shares from value added indicators are computed from the ratio of the domestic value added used to produce manufacturing exports over the total value added used in world manufacturing exports. Likewise, market shares with value added for the manufacturing final demand (VAMFD) are computed from the ratio of total domestic value added used in exports to satisfy manufacturing final demand over the world value added exported to address this same demand. Intermediary exports of services and other nonmanufacturing industries, like raw materials, used as input by the manufacturing global value chains are thus also encompassed.

\section{Chart A1: Export market shares of value added for manufacturing final demand (left) and ratio of gross manufacturing exports market share and VAMFD export market share (right)}

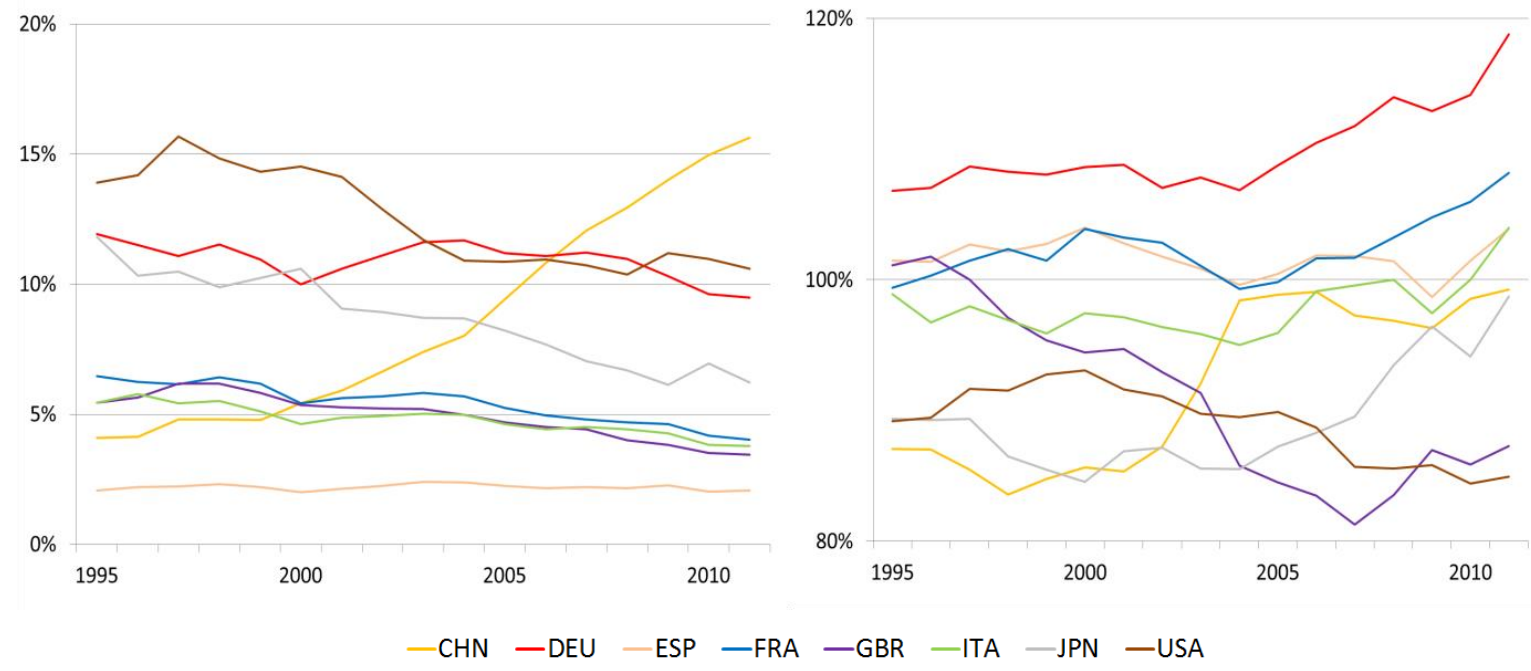

Source: WIOD and authors' calculations.

Chart A1 shows the export market shares within the manufacturing global value chains, i.e computed with data on value added for manufacturing final demand (left panel). As they also include indirect services, the diagnosis for France and for the United Kingdom improve compared to gross exports (respectively 0.8 and 0.3 points in 2011); whereas Germany and China relatively lose market shares with the new measure (respectively -1.8 and -1.4 points). Spain and the United States market shares remain quite stables ( +0.1 and -0.2 points). The right panel in the same Chart shows the ratio of market shares computed from gross to VAMFD data, pointing that the development of both measures are different through time. For Germany and France, the upward trend in the ratio indicates an increasing import content in their manufacturing value chains, compared to the world average. The upper than $100 \%$ indicator for Germany also indicates a low indirect service content proportionally to the world average. On the contrary, the ratio for the United Kingdom and United States are much lesser 
than $100 \%$ and indicate a lower than average import content and a higher than average service content of their manufacturing exports. For China, VAMFD market share also increase faster than that with gross exports, especially between 2000 and 2006 (from 87\% to 99\%), mainly due to the development of its own national production chain (Kee et al. 2016).

\section{Appendix 3: Specialization within the manufacturing global value chains}

Countries in our sample specialize on services sectors within the manufacturing value chain to the detriment of manufacturing industries (see table A5). This movement is more pronounced in the European countries, especially in France, and also on the United States. In contrast, both Asian countries present a more bumpy profile with a lesser growth rate within the services sectors (Japan) or a stronger growth rate in some industries (China).

In order to assess the different measures of sectorial participation within the manufacturing value chains, this appendix compares the Balassa indicator computed from gross exports to the Balassa indicator from exports in value added for the manufacturing final demand. The differences between those two indicators highlight the role of non-exchangeable goods or services within the manufacturing production chains and thus the contribution of upstream industries. Table A6 presents the gaps for 2011 between both Balassa indicators computed from gross exports and from value added exports for manufacturing final demand. More precisely the values presented in the table are computed as the former indicator minus the latter indicator. Indexes lower than 0 indicate that the Balassa indicator computed from gross exports is underestimated relatively to the value added actually produced by the industry; while indexes higher than 0 indicate that the Balassa indicator from gross exports is overestimated.

Results do not stress a common trend between European countries. In general, rich countries in the sample upward their comparative advantages toward services industries at the expense of their manufacturing industries. But this trend is unequal between countries and industries. France and Spain present the strongest trend toward service industries whereas Germany presents a relatively neutral profile and the United Kingdom presents an opposite relative trend against its services industry revealed comparative advantages. Indeed, countries for which the service content of manufacturing exports is higher than the world average normally upward their revealed comparative advantages in services. This content is exported indirectly and thus not counted by traditional Balassa indicators. And, likewise, countries for which the domestic manufacturing content of their manufacturing exports is lower than the world average downward their revealed comparative advantages in manufacturing. 
Table A5: Growth rate of Balassa specialization indicator within the manufacturing global value chain (1995 - 2011)

\begin{tabular}{|c|c|c|c|c|c|c|c|c|}
\hline Industry & China & Germany & Spain & France & $\begin{array}{c}\text { United } \\
\text { Kingdom }\end{array}$ & Italy & Japan & $\begin{array}{l}\text { United } \\
\text { States }\end{array}$ \\
\hline Agriculture, Hunting, Forestry and Fishing & $-42 \%$ & $-15 \%$ & $-24 \%$ & $-28 \%$ & $-45 \%$ & $-32 \%$ & $-6 \%$ & $48 \%$ \\
\hline Mining and Quarrying & $-51 \%$ & $-90 \%$ & $-71 \%$ & $-78 \%$ & $-52 \%$ & $-61 \%$ & $0 \%$ & $-8 \%$ \\
\hline Food, Beverages and Tobacco & $-25 \%$ & $9 \%$ & $25 \%$ & $-19 \%$ & $5 \%$ & $24 \%$ & $-12 \%$ & $2 \%$ \\
\hline Textiles and Textile Products & $-32 \%$ & $-32 \%$ & $22 \%$ & $-23 \%$ & $-36 \%$ & $-34 \%$ & $-3 \%$ & $-2 \%$ \\
\hline Leather, Leather and Footwear & $-23 \%$ & $-14 \%$ & $-23 \%$ & $1 \%$ & $-38 \%$ & $3 \%$ & $-2 \%$ & $-3 \%$ \\
\hline Wood and Products of Wood and Cork & $-9 \%$ & $-13 \%$ & $-13 \%$ & $-10 \%$ & $-4 \%$ & $-32 \%$ & $-17 \%$ & $10 \%$ \\
\hline Pulp, Paper, Paper, Printing and Publishing & $27 \%$ & $12 \%$ & $24 \%$ & $22 \%$ & $-3 \%$ & $19 \%$ & $-67 \%$ & $23 \%$ \\
\hline Coke, Refined Petroleum and Nuclear Fuel & $-40 \%$ & $-14 \%$ & $-49 \%$ & $-14 \%$ & $-17 \%$ & $-67 \%$ & $-119 \%$ & $-22 \%$ \\
\hline Chemicals and Chemical Products & $16 \%$ & $-6 \%$ & $25 \%$ & $-8 \%$ & $-9 \%$ & $9 \%$ & $-3 \%$ & $-6 \%$ \\
\hline Rubber and Plastics & $4 \%$ & $-2 \%$ & $-7 \%$ & $-15 \%$ & $-11 \%$ & $-22 \%$ & $19 \%$ & $-5 \%$ \\
\hline Other Non-Metallic Mineral & $-36 \%$ & $-23 \%$ & $-13 \%$ & $11 \%$ & $-20 \%$ & $-12 \%$ & $17 \%$ & $5 \%$ \\
\hline bricated Metal & $19 \%$ & $14 \%$ & $2 \%$ & $7 \%$ & $-24 \%$ & $8 \%$ & $14 \%$ & $-13 \%$ \\
\hline Machinery, Nec & $65 \%$ & $6 \%$ & $-3 \%$ & $7 \%$ & $-5 \%$ & $20 \%$ & $32 \%$ & $-13 \%$ \\
\hline Optical Equipment & $66 \%$ & $5 \%$ & $-33 \%$ & $-34 \%$ & $-44 \%$ & $4 \%$ & $-4 \%$ & $-77 \%$ \\
\hline Transport Equipment & $128 \%$ & $15 \%$ & $-29 \%$ & $14 \%$ & $44 \%$ & $3 \%$ & $-20 \%$ & $25 \%$ \\
\hline Manufacturi & $31 \%$ & $-2 \%$ & $-6 \%$ & $-8 \%$ & $-2 \%$ & $-33 \%$ & $15 \%$ & $-23 \%$ \\
\hline Gas and Water Supply & $35 \%$ & $18 \%$ & $23 \%$ & $-51 \%$ & $2 \%$ & $9 \%$ & $-92 \%$ & $-43 \%$ \\
\hline Construction & $-46 \%$ & $-29 \%$ & $32 \%$ & $4 \%$ & $33 \%$ & $30 \%$ & $-132 \%$ & $-80 \%$ \\
\hline Sale, Maintenance and Repair & & $44 \%$ & $36 \%$ & $33 \%$ & $45 \%$ & $17 \%$ & $-142 \%$ & $-13 \%$ \\
\hline Wholesale Trade and Commission Trade & $12 \%$ & $-5 \%$ & $29 \%$ & $29 \%$ & $1 \%$ & $2 \%$ & $94 \%$ & $95 \%$ \\
\hline Retail Trade & $2 \%$ & $5 \%$ & $30 \%$ & $22 \%$ & $26 \%$ & $-10 \%$ & $50 \%$ & $-20 \%$ \\
\hline Hotels & $7 \%$ & $-54 \%$ & $-27 \%$ & $24 \%$ & $83 \%$ & $25 \%$ & $-81 \%$ & $-84 \%$ \\
\hline Inland Transport & $-22 \%$ & $28 \%$ & $3 \%$ & $23 \%$ & $-14 \%$ & $21 \%$ & $-8 \%$ & $51 \%$ \\
\hline Water Transport & $200 \%$ & $8 \%$ & $-37 \%$ & $283 \%$ & $-43 \%$ & $-57 \%$ & $138 \%$ & $10 \%$ \\
\hline Air Transport & $-10 \%$ & $52 \%$ & $42 \%$ & $14 \%$ & $16 \%$ & $-65 \%$ & $3 \%$ & $27 \%$ \\
\hline Other Supporting and Auxiliary Transport Activities & $-56 \%$ & $112 \%$ & $34 \%$ & $33 \%$ & $7 \%$ & $33 \%$ & $7 \%$ & $22 \%$ \\
\hline Post and Telecommunications & $137 \%$ & $-42 \%$ & $2 \%$ & $-5 \%$ & $16 \%$ & $52 \%$ & $-83 \%$ & $41 \%$ \\
\hline Financial Intermediation & $8 \%$ & $-34 \%$ & $-14 \%$ & $67 \%$ & $43 \%$ & $44 \%$ & $-67 \%$ & $136 \%$ \\
\hline Real Estate Activities & $13 \%$ & $29 \%$ & $64 \%$ & $56 \%$ & $22 \%$ & $43 \%$ & $-71 \%$ & $-51 \%$ \\
\hline Renting of M\&Eq and Other Business Activities & $166 \%$ & $19 \%$ & $42 \%$ & $14 \%$ & $71 \%$ & $31 \%$ & $-54 \%$ & $3 \%$ \\
\hline Public Admin and Defence; Compulsory Social Security & $379 \%$ & $42 \%$ & $177 \%$ & $-79 \%$ & $70 \%$ & $20 \%$ & $-33 \%$ & $167 \%$ \\
\hline Education & $4 \%$ & $185 \%$ & $82 \%$ & $254 \%$ & $-20 \%$ & $-5 \%$ & $-37 \%$ & $45 \%$ \\
\hline Health and Social Work & $581 \%$ & $-42 \%$ & $1 \%$ & $808 \%$ & $-45 \%$ & $-61 \%$ & $-63 \%$ & $42 \%$ \\
\hline Other Community, Social and Personal Services & $40 \%$ & $10 \%$ & $25 \%$ & $760 \%$ & $41 \%$ & $10 \%$ & $-131 \%$ & $56 \%$ \\
\hline
\end{tabular}

Source: WIOD and authors' calculations.

The case of the financial intermediation industry is interesting. For this industry, the Balassa indicator from manufacturing value chains is significantly higher than the traditional indicator for China (1.1 point), France and Japan (0.7 points each); whereas it is lower for the United Kingdom (3.2 points) and United States (1.4 point), which are great exporters in this industry. Indeed, these two countries have an important comparative advantage in direct exports, with Balassa indicators of respectively 4.9 and 3 with gross data. Other countries export these services rather indirectly as input for their manufacturing output. Moreover, indirect exports of services are relatively important compared to direct exports and consequently the comparative advantages are toggle when considering both direct and indirect value added within the production chains. Another interesting example is the Educational sector, which is most frequently exported indirectly as input for manufacturing production. Thus, comparative advantages of direct exporters, like the United Kingdom and the United States, relatively 
decrease when measured by value added data as indirect exports, as well as indirect exporters, are taken into account and increase their revealed advantages.

\section{Table A6: Balassa indicator in gross exports minus in value added for manufacturing final demand exports (2011)}

\begin{tabular}{|c|c|c|c|c|c|c|c|c|}
\hline Industry & China & Germany & Spain & France & $\begin{array}{c}\text { United } \\
\text { Kingdom }\end{array}$ & Italy & Japan & $\begin{array}{l}\text { United } \\
\text { States }\end{array}$ \\
\hline Agriculture, Hunting, Forestry and Fishing & 1.3 & 0.1 & 0.9 & 0.7 & \begin{tabular}{l|l} 
& 0.0
\end{tabular} & 0.2 & -0.1 & 0.5 \\
\hline Mining and Quarrying & 0.6 & 0.0 & 0.0 & 0.0 & 0.2 & 0.0 & 0.0 & -0.1 \\
\hline Food, Beverages and Tobacco & 0.3 & 0.2 & 0.2 & 0.6 & -0.4 & 0.2 & -0.1 & 0.0 \\
\hline Textiles and Textile Products & 0.7 & 0.1 & 0.2 & 0.1 & -0.1 & 0.2 & 0.0 & 0.0 \\
\hline Leather, Leather and Footwear & 1.0 & 0.0 & 0.2 & -0.1 & -0.1 & 1.0 & 0.0 & 0.0 \\
\hline Wood and Products of Wood and Cork & -0.8 & 0.4 & 0.1 & 0.1 & -0.3 & $f 0.4$ & 0.2 & 0.1 \\
\hline Pulp, Paper, Paper, Printing and Publishing & -0.5 & 0.7 & 0.0 & 0.2 & -0.2 & 0.1 & -0.7 & 0.2 \\
\hline Coke, Refined Petroleum and Nuclear Fuel & -1.0 & 0.2 & 1.4 & 0.4 & 0.8 & 0.7 & -1.2 & -0.2 \\
\hline Chemicals and Chemical Products & 0.3 & 0.2 & 0.1 & 0.8 & -0.2 & 0.3 & 0.0 & -0.1 \\
\hline Rubber and Plastics & 0.2 & 0.4 & 0.1 & 0.4 & -0.2 & 0.6 & 0.2 & -0.1 \\
\hline Other Non-Metallic Mineral & fo.2 & 0.5 & 0.9 & 0.3 & -0.1 & 0.7 & 0.2 & 0.0 \\
\hline Basic Metals and Fabricated Metal & 0.3 & 0.2 & 0.0 & 0.0 & 0.0 & 0.2 & 0.1 & -0.1 \\
\hline Machinery, Nec & 0.2 & 0.0 & 0.1 & 0.2 & -0.2 & 0.7 & 0.3 & -0.1 \\
\hline Electrical and Optical Equipment & 1.1 & -0.1 & 0.1 & 0.3 & -0.2 & 0.0 & 0.0 & -0.8 \\
\hline Transport Equipment & 0.1 & 0.2 & 0.4 & 0.8 & -0.1 & 0.3 & -0.2 & 0.3 \\
\hline Manufacturing, Nec; Recycling & 0.2 & 0.0 & -0.3 & 0.1 & -0.3 & 0.0 & 0.2 & -0.2 \\
\hline Electricity, Gas and Water Supply & 1.3 & 1.7 & -0.8 & 0.5 & -0.5 & 0.7 & -0.9 & -0.4 \\
\hline Construction & 1.4 & 0.1 & 1.9 & -1.1 & -0.1 & 1.4 & -1.3 & -0.8 \\
\hline Sale, Maintenance and Repair & 0.0 & -1.1 & 0.1 & -1.8 & -1.6 & 0.0 & -1.4 & -0.1 \\
\hline Wholesale Trade and Commission Trade & 0.1 & -0.2 & -0.7 & -0.8 & -0.5 & -0.1 & 0.9 & 0.9 \\
\hline Retail Trade & 1.0 & -0.9 & -1.4 & -1.7 & -1.3 & 1.9 & 0.5 & -0.2 \\
\hline Hotels and Restaurants & 0.5 & 0.4 & 0.9 & -1.1 & 1.8 & 1.8 & -0.8 & -0.8 \\
\hline Inland Transport & 0.6 & -0.3 & 0.1 & -0.3 & -0.4 & 1.2 & -0.1 & 0.5 \\
\hline Water Transport & 0.7 & 0.7 & 0.0 & -0.2 & 0.7 & 0.3 & 1.4 & 0.1 \\
\hline Air Transport & 0.5 & -0.2 & 0.1 & 0.1 & -0.4 & 0.3 & 0.0 & 0.3 \\
\hline Other Supporting and Auxiliary Transport Activities & 0.0 & -0.5 & -0.2 & -0.7 & -0.7 & 0.1 & 0.1 & 0.2 \\
\hline Post and Telecommunications & 0.3 & 0.0 & 0.3 & 0.2 & 0.7 & $f 0.2$ & -0.8 & 0.4 \\
\hline Financial Intermediation & 1.1 & -0.1 & 0.0 & -0.7 & 3.2 & 0.4 & -0.7 & 1.4 \\
\hline Real Estate Activities & 0.7 & -1.5 & 1.5 & -1.5 & -0.5 & 1.4 & 0.7 & -0.5 \\
\hline Renting of M\&Eq and Other Business Activities & 0.3 & -0.9 & 0.5 & -1.1 & 0.4 & 0.4 & -0.5 & 0.0 \\
\hline Public Admin and Defence; Compulsory Social Security & 0.1 & -0.9 & 0.9 & -0.9 & 0.3 & $f 0.1$ & -0.3 & 1.7 \\
\hline Education & 0.5 & -1.8 & -1.7 & -2.9 & 2.6 & 0.8 & -0.4 & 0.5 \\
\hline Health and Social Work & 1.0 & -0.2 & -2.4 & 1.0 & -0.1 & 0.2 & -0.6 & 0.4 \\
\hline Other Community, Social and Personal Services & 0.0 & -1.2 & 0.0 & -0.2 & 1.5 & 0.5 & -1.3 & 0.6 \\
\hline Private Households with Employed Persons & 0.0 & 0.0 & 0.0 & -1.2 & 1.0 & 0.0 & 0.0 & -2.1 \\
\hline
\end{tabular}

Source: WIOD and authors' calculations. 